Financial Constraints,

Uses of Funds,

and Firm Growth

\section{An International Comparison}

Asli Demirgüç-Kunt

Voiislav Maksimovic
The findings suggest that across very different financial systems, financial markets and intermediaries have a comparative advantage in funding short-term investment. An active, though not necessarily large, stock market and high scores on an index of respect for legal norms are associated with faster than predicted rates of firm growth. Government subsidies to industry do not increase the proportion of firms growing faster than predicted.

The World Bank

Policy Research Department

Finance and Private Sector Development Division October 1996 


\section{Summary findings}

Demirgüç-Kunt and Maksimovic focus on two issues. First, they examine whether firms in different countries finance long-term and short-term investment similarly. Second, they investigate whether differences in financial systems and legal institutions across countries are reflected in the ability of firms to grow faster than they might have by relying on their internal resources or short-term borrowing.

Across their sample, they find:

- Positive correlations between investment in plant and equipment and retained earnings.

- Negative correlations between investment in plant and equipment and external financing.

- Negative correlations between investment in shortterm assets and retained earnings.

- Positive correlations between investment in shortterm assets and external financing.

These findings suggest that across very different financial systems, financial markets and intermediaries have a comparative advantage in funding short-term investment.

For each firm in their sample, they estimate a predicted rate at which it can grow if it does not rely on long-term external financing. They show that the proportion of firms that grow faster than the predicted rate in each country is associated with specific features of the legal system, financial markets, and institutions.

An active, though not necessarily large, stock market and high scores on an index of respect for legal norms are associated with faster than predicted rates of firm growth.

They present evidence that the law-and-order index measures the ability of creditors and debrors to enter into long-term contracts. Government subsidies to industry do not increase the proportion of firms growing faster than predicted.

This paper - a product of the Finance and Private Sector Development Division, Policy Research Department - is part of a larger effort in the department to understand the impact of financial constraints on firm growth. Copies of the paper are available free from the World Bank, $1818 \mathrm{H}$ Street NW, Washington, DC 20433. Please contact Paulina SintimAboagye, room N9-030, relephone 202-473-7644, fax 202-522-1155, Internet address psintimaboagye@worldbank.org. October 1996. (49 pages)

The Policy Research Working Paper Series disseminates the findings of work in progress to encourage the exchange of ideas about development issues. An objective of the series is to get the findings out quickly, even if the presentations are less than fully polished. The papers carry the names of the authors and should be used and cited accordingly. The findings, interpretations, and conclusions are the authors' oun and should not be attributed to the World Bank, its Executive Baard of Directors, or any of its member countries. 


\title{
FINANCIAL CONSTRAINTS, USES OF FUNDS AND FIRM GROWTH: AN INTERNATIONAL COMPARISON
}

\author{
Aslı Demirgüç-Kunt \\ Vojislav Maksimovic*
}

* The authors are at the World Bank and the University of Maryland at College Park respectively. We thank Jerry Caprio, Murray Frank, Ross Levine, Mary Shirley, Fabio Schiantarelli, Sheridan Titman, Ian Tonks and the participants of the June 1966 World Bank Conference "Term Finance: Does it Matter?" for their comments and Jim Kuhn for help with the data. 



\section{INTRODUCTION}

Both the theoretical and the empirical literature in corporate finance demonstrate a link between firms' financing and investment decisions. The link is due to market imperfections caused by conflicts of interest and informational asymmetries between the firm and investors. These imperfections constrain the ways a firm can fund investment projects. The magnitude of this effect may depend on the financial market and the institutions, such as financial intermediaries. A key question is whether differences in financial systems across countries affect the way firms finance investments, and if so, how?

In this paper we focus on two questions. Do firms in economies with different financial systems and legal systems finance long-term and short-term investment differently? Can specific differences in financial systems and legal institutions explain the differences in the proportion of firms that grow at rates requiring long-term external financing?

Similar patterns in firms' use of capital from external sources to finance long-term and short-term investment in very different financial systems would suggest that these patterns cannot be explained by the institutional features specific to any single system. Our results indicate that is the case. In our sample of both developed and developing countries, firms use their internal funds to finance longterm investments in plant and equipment. The use of external financing, including long-term and short-term debt, is correlated negatively with long-term investment. By contrast, investment in shortterm assets, such as inventories and credit to customers, is positively correlated with external financing. These patterns suggest that external suppliers of capital have a comparative advantage in financing short-term assets, perhaps because of lower contracting and monitoring costs. Thus, a principal role of external finance in established firms may be in providing financing for their liquid assets, allowing them to redeploy internal funds to finance long-term investment. 
The similarity in the observed patterns of financing in countries with developed and emerging financial markets has an important policy implication for the foreign development financing. The fact that established firms in developed economies finance their investments internally suggests that financial markets and banks have a comparative advantage in funding short-term investments. If so, policies that encourage banks and investors to finance investments in developing countries for which they do not have a comparative advantage may have unexpected costs.

The second question we investigate is whether specific differences in financial systems and legal institutions are associated with firm growth at rates higher than could be realized using internal financing. A comparison of debt maturities of firms in developed and developing countries suggests that greatest difference between systems is in the provision of long-term credit (Demirgüç-Kunt and Maksimovic (1996a)). Accordingly, we focus on the effect of financial systems and institutions on long-term financing, i.e. long-term debt or external equity. For each firm in our sample we estimate a financial planning model to obtain the maximum growth rate it could attain without access to longterm financing. The effect of differences in financial systems on investment is then measured by comparing these predicted growth rates with growth rates realized by firms in countries with differing levels of financial market development. Our approach enables us to identify specific characteristics of the financial system that are associated with long-term financing of firm growth. Thus, we provide a test on the micro-level of the hypothesis, advanced by King and Levine (1993) and Levine and Zervos (1995), that the development of financial markets and intermediaries is an important determinant of economic growth.

In our empirical tests we focus on two types of financial and legal system characteristics that may affect the provision of equity and long-term debt financing. First, we examine the association between the effectiveness of the legal system and the financing of firm growth. A firm that wishes to obtain long-term financing must credibly commit to control opportunistic behavior by insiders. In 
particular, long-term creditors commonly attempt to constrain debtors' opportunistic behavior by debt convenants. For convenants to be effective, there must exist effective legal institutions that deter violations and can compel compensation for infractions. ${ }^{1}$

Second, we examine the association between the development of stock markets and financial intermediaries and firm growth. Markets and intermediaries are important both as direct sources of capital and mechanisms for monitoring requires that investors have access to information about firms' activities.

The existence of developed and active financial markets and a large intermediary sector should increase the ability of firms to raise long-term capital. ${ }^{2}$

Empirically, we find that there is a strong relationship between the development of the legal system, financial markets and intermediaries and the proportion of firms growing at rates requiring long-term external financing. In particular, an active, although not necessarily large, stock market, and high scores on an index of respect for legal norms are associated with firm growth financed by long-term external debt and equity. High scores in the legal index are also associated with the availability of long-term debt.

This paper is related to the literature on internal and external financing of investment that developed from the work of Myers and Majluf (1984). Myers and Majluf (1984) argue that financial market imperfections make it costly for firms with inadequate cash flow to obtain external financing. The imperfections mean that when the firm does obtain external financing it does so according to a pecking order: debt is preferred to equity as the market for loans is subject to less adverse selection

\footnotetext{
${ }^{1}$ For a more extensive discussion of the role of commitments and the legal system in investment see Williamson (1994, 1988) and Shleifer (1994). For a cross-country empirical analysis of the effect of institutional differences on debt maturity see Demirgüç-Kunt and Maksimovic (1996b).

${ }^{2}$ For a theoretical treatment of the role of financial markets and intermediaries see Allen (1993), Diamond (1996, 1993), and Holmstrom and Tirole (1993).
} 
than the market for equity. Myers and Majluf do not explore the possibility that different types of investment may be associated with different pecking orders. Our empirical estimates of sources and uses of financing may be viewed as tests of whether the Myers-Majluf pecking order is consistent with the data for the financing of two different categories of investment across a sample of countries. Our approach also has implications for the related literature on financial constraints and investment. Following Fazzari, Hubbard and Petersen (1988), observed correlations between long-term investment and internal financing in a sample of firms have been interpreted as indicating that those firms are financially constrained. This interpretation has been questioned by Kaplan and Zingales (1995). By contrast, for our cross-county investigation of financial systems we estimate the excess growth made possible by external financing for each firm in the sample. Thus, our approach offers an alternative method for directly identifying those firms that are financially constrained.

This paper is also related to the literature on the role of the stock markets in the provision of investment capital. Morck, Vishny and Shleifer (1989) relate stock prices to investment outlays by firms and conclude that the stock market has a very limited role in directing investment. While their work is pioneering, it is constrained by the fact that they have access only to US data. Thus, they cannot gauge the role of the stock market across different levels of financial market development.

There exists a related literature comparing the financial policies of firms in different countries. Rajan and Zingales (1995) compare financial structures in a sample of developed countries. DemirgüçKunt and Maksimovic (1996a,b) analyze how institutional and economic differences between countries affect firms' debt-equity ratios and maturity choice. This paper explores the links between financial markets and institutions and firms' ability to obtain debt and equity financing. ${ }^{3}$

${ }^{3}\{\%$ In contemporaneous work Rajan and Zingales (1996) investigate the relationship between financial dependence and industry growth. While some of the issues they address are a subset of the topics we cover in section three, their paper differs in major respects. First, Rajan and Zingales (1996) do not use the indicators of stock market liquidity, the legal system or government subsidies that are the major focus of that section. 
The remainder of the paper is organized as follows. In section 2 we discuss the composition of firms' investment expenditures and the sources of financing in the countries in our sample. We investigate whether there exist associations between sources of financing and categories of investment expenditures. In section 3 we analyze how the development of markets and institutions affects firms' ability to obtain external financing. Section 4 provides some sensitivity tests. Section 5 concludes.

\section{SOURCES OF FINANCING AND COMPOSITION OF INVESTMENT}

In an economy with perfect financial markets any firm is able to finance any positive net present value project. If the costs of investment exceed the firm's internal resources, or if the firm prefers to use its internal funds to pay dividends, it can raise the funds required for investment in the capital market or borrow from banks. ${ }^{4}$ In such idealized markets, the source of capital used to finance investment is irrelevant and financial constraints do not constrain firms' growth.

In actual financial markets there exist several imperfections that may impose costs on firms that obtain investment funds externally. Many of these imperfections are rooted in conflicts of interest between investors and the firms' insiders. The firms' insiders have an incentive to exploit outside investors by investing in projects that benefit insiders and may lower the value of the outsiders' investment. ${ }^{5}$ In order to protect their investment, outside investors and creditors have several options. They may require that mechanisms be put in place to monitor the actions of the firm. They may also attempt to constrain the firm contractually from engaging in opportunistic behavior. This monitoring and legal enforcement is costly. If these measures are not completely effective, then investors will take into account the cost of expected opportunistic behavior when transacting with the firm. As a

Second, they use aggregate industry data, rather than firm-specific data. Third, they assume that financing requirements of industries in other countries are similar to those of corresponding US industries. By contrast we estimate the external financing need of each individual firm in our sample. Fourth, our approach separates longterm and short-term financing needs.

${ }^{4}$ This is the idealized financial market studied by Modigliani and Miller (1958).

${ }^{5}$ These conflicts were first studied systematically in finance by Jensen and Meckling (1976) and Myers (1977). 
result, the firm's cost of external capital will increase. Businesses where the costs of enforcement are large and insiders' opportunities for diverting resources abundant, may not be able to obtain investment capital at any price. ${ }^{6}$

These considerations of market failure suggest that there may be certain categories of investment expenditures that are easier to fund externally. In particular, liquid assets whose value is readily ascertainable and which can be readily repossessed may be easier to fund than specialized equipment. If loans can be secured by such assets separately, or if these assets can be securitized, then investment in these categories of assets can be financed externally at relatively low cost.

Since the costs of monitoring and enforcement depend on the sophistication of the financial markets and the legal system in the economy, the availability of external capital to fund long-term investment may vary systematically with the financial system in each country. Specifically, if financial market imperfections impose significant costs on firms that attempt to fund certain classes of investment externally and if the differences in financial systems are material, then we would expect to observe systematic differences across countries in the way these classes of investments are funded.

Little empirical evidence exists about the relationship between the sources of capital and the funding of categories of investment across countries. For our empirical analysis of this issue we differentiate between investment in three types of assets that firms use in their operations. Current assets are assets with a short maturity, such as cash holdings, inventories and short-term credit extended to the firm's customers. Fixed assets consist of plant and equipment used to produce output. The third, residual category consists of assets whose maturity is greater than a year but which are not fixed assets. These assets include such items as trademarks and patents purchased by the firm. They may also include investment holdings in other firms.

\footnotetext{
${ }^{6}$ See the discussions of credit rationing by Stiglitz and Weiss (1981) and of adverse selection by Myers and Majluf (1984).
} 
We consider four sources of financing for investment. The firm may finance investment internally, by retaining its earnings instead of paying them out as dividends. It may also obtain capital by increasing its short-term liabilities, such as the amount it owes to its suppliers or to financial intermediaries, or by increasing long-term liabilities, such as long-term debt. Finally, the firm may issue equity, either directly to the public investors, indirectly through the conversion of convertible debt, or privately, in exchange for assets.

For each firm in the sample we obtain data series for investment in three types of assets. Short-term investment are measured by changes in the firm's current assets, $\triangle \mathrm{CA}$. Investment in fixed assets, I is measured as the sum of the change in the firms net fixed assets plus depreciation. Finally, net investment in residual assets $\triangle \mathrm{RA}$ is measured by the change in the firm's total assets less changes in the value of net fixed assets and current assets. ${ }^{7}$ By definition, changes in the firm's assets are matched by changes in the sum of the firms liabilities and the equity capital. More precisely, for each firm the following identity derived from the annual statement of changes in financial position holds:

$$
\Delta \mathrm{CA}+\mathrm{I}+\Delta \mathrm{RA}=\Delta \mathrm{STL}+\Delta \mathrm{LTL}+\Delta \mathrm{CAPITAL}+\mathrm{OCF}
$$

where $\triangle \mathrm{STL}$ is the change in current liabilities, $\triangle \mathrm{LTL}$ is the change in long-term liabilities, $\triangle C A P I T A L$ is the change in issued equity and OCF is the cash flow from operations. The operating cash flow is defined as the sum of earnings after taxes, less dividends, plus depreciation. All investment categories and all financing categories with the exception of $\triangle \mathrm{CAPTIAL}$ is obtained from each firm's individual financial statements. The data for $\triangle$ CAPTIAL is calculated directly from the identity. Thus, $\triangle$ CAPTIAL includes all increases in the firm's equity resulting from public offerings, private placements, conversions of convertible securities and exchanges for assets of other businesses.

\footnotetext{
${ }^{7}$ Thus, we are implicitly assuming that residual assets do not depreciate or that they are depreciated at a low rate. This is true, for example, of long term imvestments in other firms.
} 
We focus on the relationship between changes in investment $\triangle \mathrm{CA}$ and $\mathrm{I}$ and changes is in the firm financing ( $\triangle \mathrm{STL}, \triangle \mathrm{LTL}, \triangle \mathrm{CAPITAL}$ and $\mathrm{OCF})$. In general, every term of the above identity is endogenous and varies from year to year. Thus, it is impossible in general to assign a source for a particular investment expenditure by a firm. Instead, we investigate whether changes in the financing mix are correlated with investment in current assets or fixed assets in each country in our sample.

In our empirical work we standardize the investment and liability categories by dividing each by the firm's total investment $\Delta C A+I+\Delta R$ in that year. Thus, our focus is on the proportion of total investment that each of the investment and financing categories comprises. The proportional investment variables are denoted by PERINV and PERCA for proportions of fixed and current investment respectively. The proportional financing variables are denoted as PERLTD, PERSTD, PERREQ and PERRE and denote the proportion of investment financed by long-term debt, shortterm debt, newly issued capital and cash flow from operations respectively.

An advantage of our approach is that we do not need to compare the levels of real investment in different periods. Both the numerators and the denominators of our variables are in current nominal dollars. Thus, we avoid potential measurement errors inherent in the difficult task of obtaining appropriate inflation adjustments of price of investment and the firm's stock of assets goods over time for thirty countries. ${ }^{8}$

\footnotetext{
8 There is a possibility that within year changes in the price level may affect the results. Accordingly, we recalculated the statistics presented in Table 1 below after making an adjustment for within year inflation. The results were unaffected. The consistency of results across countries with different rates of inflation also suggests that within year price-level changes do not drive our conclusions. See section 4 below for a discussion of inflation adjustments.
} 


\subsection{Sample and data}

Our sample contains both developed and developing economies. The developed countries in our sample are Austria, Australia, Belgium, Canada, Finland, France, Germany, Hong Kong, Italy, Japan, Netherlands, New Zealand, Norway, Sweden, Singapore, Spain, Switzerland, United Kingdom, United States. The developing countries are Brazil, India, Jordan, Korea, Malaysia, Mexico, Pakistan, South Africa, Thailand, Turkey and Zimbabwe.

In Table 1 we summarize some important facts about the level of economic and institutional development in the sample countries. Details of sources are given in the data Appendix. The per capita incomes in countries in our sample vary significantly. The Gross Domestic Product per Capita of ranged from $\$ 27,492$ in Switzerland to $\$ 359$ in Pakistan.

The countries also vary in the effectiveness of their legal systems in defending their property rights. As an indicator of efficiency of the state in enforcing property rights, we use a commercial index of the level of law and order in each country. The index, prepared by the International Country Risk Guide, aggregates reports by a panel of more than a hundred analysts on a six point scale. Low levels of the index denote less reliance on the legal system to mediate disputes. This indicator has been used in previous studies comparing institutions in different countries, for example, Knack and Keefer (1995).

We also present two other macro-economic indicators. The average inflation rate over the sample period provides both an indicator of the governments management of the economy and evidence on whether the local currency provides a stable measure of value to be used in long-term contracting. There are major variations in the average rate of inflation in the sample countries. The average annual rate of inflation is highest in Brazil, at $327.6 \%$, and lowest in Japan at $1.5 \%$ per annum. 
The remaining macro-economic indicator in Table 1 measures the average annual growth rate of the

Gross Domestic Product over the sample period. If investment opportunities in an economy are correlated, there should be a relationship between the rate of growth of individual firms and the growth rate of the economy. Thus, the aggregate growth rate may serve as a control variable in crosscountry comparisons of firm financing choices and their growth rates.

Our last indicator measures the governments intervention in the corporate sector. These affect financial structure decisions because implicit or explicit guarantees by the government may distort market incentives and permit firms to obtain long-term loans on favorable terms. Our measure of the governments intervention is the level of government grants as a percentage of the Gross Domestic Product. As Table 1 reveals, the level of government subsidies is significant is some countries, and exceeds $10 \%$ of the GDP in the case of Brazil.

The firm-level data consists of financial statements of mostly established firms in each country reported, for the developed economies, by Global Vantage and for the developing countries, by the IFC Developing Countries database. ${ }^{9}$ These databases cover the largest publicly traded firms in each

\footnotetext{
${ }^{9}$ Financial reporting practices differ in detail across the countries in our sample. The principal reporting requirements, are described in Fitzgerald, Stickler and Watts (1979). A direct comparison of the key provisions of the accounting systems shows that they broadly conform to US practice. The most significant concern in interpreting the financial statements from the sample of countries pertains to differences arising from different levels of inflation and the difference in how inflation is treated in financial statements. This problem is likely to be most severe for Brazil, Mexico and Turkey, which, as Table 1 shows, had the highest rates of inflation during the sample period. In contrast to the other countries, fixed assets are stated at their historical cost, the reported financial statements of firms in Mexico and Brazil were adjusted during part or the whole of the sample period. Since 1984, listed firms in Mexico have been required to use current replacement costs for valuing inventories and property, plant and equipment. Other nonmonetary assets and stockholders equity are restated using specified consumer price indices. Any gains or losses resulting from inflation adjustments are reported in the income statement. The financial accounts of Brazilian firms have been adjusted for inflation throughout the sample period, although specific requirements were modified in 1987 and again in 1989. Permanent assets and shareholder equity are adjusted using specified government indices. As in the case of Mexico, the adjustment was reflected in the income statement. However, observers noted that the increases in the specified index did not fully reflect the realized inflation. Turkey, which had the third highest average inflation rate, 241\%, did not permit inflation adjusted accounting (Price Waterhouse (1993a)). The high average return on assets reported by Turkish firms may be caused by this underreporting. Thus care must be exercised in comparing the results for Brazil and Turkey with those of other countries in the sample. To check the robustness of the cross-country results, in Section 4 we omit the high inflation countries.
} 
country. For the developed countries in our sample data is available for the period 1983-91. For the developing countries the period of data availability varies, but is usually between 1980-88. Coverage by county and line numbers of Global Vantage data used to construct firm-specific variables are described in the Appendix.

\subsection{Sources and uses of capital}

Figure 1 depicts the mean proportions of total annual gross investment accounted for by each of the three categories defined above for our sample of countries. Figure 1 reveals considerable variation in the investment mix of across the sample. Interestingly, the four countries with the highest proportions of fixed investment to total investment are developing countries. As revealed in Table 1, three of them, Brazil, Mexico and Turkey, are high inflation countries.

Figure 2 depicts the proportions of total gross investment financed by each of these four methods in our sample during 1980-91. The countries in Figure 2 are ordered by the proportion of their investment financed by long-term debt. Inspection of the figure reveals that developing countries are heavily concentrated on the left. Thus, firms in these countries use less long-term debt to fund investment. Developing countries, such as Jordan, Turkey and South Africa also tend to be concentrated among countries in which firms in our sample rely heavily on internal financing. Developed countries, such as Australia, Hong Kong and Spain, predominate among countries in which firms rely least on internal funding. No such clear patterns exist for other sources of financing. ${ }^{10}$

\footnotetext{
${ }^{10}$ There are also some differences in investment and financing patterns by size. We classify the largest quartile of firms by asset size in each country as "large" and the smallest quartile as "small." A larger proportion of large firms' investment goes into fixed assets, while a larger portion of the small firms's investment is in current assets. Large firms rely more on cash from operations and long-term debt, small firms rely more on new equity and short-term debt.
} 
To investigate the relationship between investment composition and financing composition, we regress the percentage of fixed investment PERINV on three of the financing components, PERLTD, PERSTD and PEREQ for each country separately. We drop the fourth source of funding, the proportion of funds provided by operations, since the sum of all the standardized sources of funds equals one. ${ }^{11}$ To reduce measurement errors, for each firm we calculate the investment and financing fractions annually, and then we average the fractions over the sample period. Thus, for each firm we have one data-point.

The results of the regression of the fraction of the firm's total investment that is fixed assets on the fraction of funding provided by long-term debt, short-term debt and equity are presented in the first three columns of Table 2A. We interpret the coefficients as measures of association, and do not ascribe a causal relationship between the firm's financing mix and its decision to invest in fixed assets.

The coefficients of PERSTD are uniformly negative and in almost all cases significant at the $1 \%$ level. The coefficients of PERLTD and PEREQ are also predominantly negative and significant. Thus, in all countries in our sample a firm that invests predominantly in fixed assets is likely to have a financing mix that is weighted away from all types of external financing and towards financing from retained earnings.

For each country we also test the size of the coefficients pertaining to each form of financing. The differences between the coefficients and their significance levels are reported in the last three columns of Table 2A. Inspection of the table reveals that absolute value of the coefficient of PERSTD exceeds the absolute value of the coefficients of PERLTD and PEREQ for most countries.

\footnotetext{
${ }^{11}$ We obtain similar qualitatve results when simple correlation coefficients between PERINV and PERLTD, PERSTD, PEREQ and PERRE are compared.
} 
The absolute values of the coefficients of PERLTD and PEREQ cannot be ranked as clearly. ${ }^{12}$ The inverse relationship between investment in fixed assets and external financing is strongest with respect to short-term liabilities and less strong with respect to long-term debt and equity. This ordering of coefficients is unaffected when the level of investment relative to total assets, is added to the estimating equations as an additional regressor.

In Table 2B we report country regressions of PERCA on PERLTD, PERSTD and PEREQ. The results are in sharp contrast with those reported in Table $2 \mathrm{~A}$. The coefficients of the three financing variables are predominantly positive. This pattern implies a negative relationship between investment in short-term assets and internal financing. Thus, investment in short-term assets, such as inventories and accounts receivable, is associated with external financing. ${ }^{13}$

The values of the coefficients are compared in the final three columns of Table 2B. A statistical comparison of the coefficients shows that the coefficient of PERSTD is the largest coefficient in the majority of the sample countries, whereas the coefficients of PERLTD and PEREQ cannot be ranked as clearly. ${ }^{14}$ In sum, an increase in the fraction of investment going to short-term assets is associated with increases in the fraction of total investment being financed by increases in short-term liabilities mix. The proportions being financed by equity and long-term debt also increase, but less so. It is also associated with a decrease in the fraction of the funds for investment that are internally generated. As in the case of fixed investment, this ranking of coefficients is unaffected when the level of investment, relative to total assets, is added to the estimating equations as an additional regressor.

\footnotetext{
${ }^{12}$ In nine countries the absolute value of the coefficient of PERLTD is greater than the absolute value of PEREQ. In six cases the opposite is true.

${ }^{13}$ Note that when securities are sold, the funds raised temporarily increase the firm's current assets. When the funds are disbursed this effect disappears. Thus, a positive correlation between current assets and external financing naturally occurs immediately after the issue and a negative one shortly thereafter. Similarly, retained earnings not otherwise used increase the firms current assets. Such transitory shocks are unlikely to systemmatically bias based on annual data averaged over the sample period.

${ }^{14}$ In 11 cases the coefficient of PERLTD is higher than the coefficient of PEREQ. In four cases the opposite is true.
} 
The tables indicate that the shares of long-term debt and equity are positively correlated with the share of short-term investments in total investment and negatively correlated with the share of fixed plant and equipment in total investment. The prevalence of this pattern across our sample of countries with very different financial systems suggests that it is caused by differences in the characteristics of short-term and fixed investments that expose external investors to greater potential losses when they fund fixed investment. Established firms use capital markets and intermediaries to obtain liquidity and finance short-term investment, such as accounts receivable and inventories, that allows the firm to use its own resources to finance long-term investment or dividends. The correlation between internal financing and fixed investment in fixed assets does not imply that differences in access to external financing does not affect firm's ability to exploit growth opportunities. Firms need to invest in both types of assets to grow. External financing of short-term assets permits the firm to redirect its resources towards funding investment or paying out dividends. Moreover, some firms, for example firms with particularly good investment opportunities, may at the margin finance long-term investment with external funds.

Our results have implications for the literature on capital structure in corporate finance. Myers and Majluf (1984) argue that there is a pecking order in the sources of funds firms use for investment. In order to minimize the costs of adverse selection in the market for external finance, firms prefer to fund investment internally, and use external financing only when internal funds are not available. When external funds are used, debt is preferred to equity because it is less subject to adverse selection.

The results in Table 2 suggest two modifications to the pecking order proposed by Myers and Majluf (1984). Empirically, the proportion of internal funds used to finance investment increases only as the share of fixed investment in the firm's total investment increases. Increases in the share of current assets in the total investment are associated with increases in the share of external sources of funds 
used. Thus, the pecking order empirically describes investment in fixed investment better than investment in short-term assets. Within the context of the Myers and Majluf (1984) model this might occur because short-term assets are easier to monitor and value, thereby reducing informational costs. ${ }^{15}$ Short-term assets can also be normally converted to cash within a year, facilitating collection.

The Myers and Majluf (1984) model focuses on the distinction between external equity and debt financing. They argue that because debt financing is less sensitive to asymmetries of information between the firm and investors, it will be preferred to equity financing when such asymmetries are significant. Our results indicate that there is an important empirical distinction between short-term debt and both long-term debt and equity in financing long-term projects. This suggests that in many cases the expected costs associated with refinancing of short-term debt may be more significant than the additional adverse selection costs equity financing over debt financing.

The signs of the associations between sources and uses of funds for short-term and long-term investment is similar in developed and developing countries. ${ }^{16}$ Thus, we do not find evidence that the financing choices in financial markets are fundamentally different in the economies in our sample.

This does not imply that firms' access to financing is similar. We next address the question whether the development of financial markets and institutions affects the growth rates of firms.

\section{EXTERNAL FINANCING AND GROWTH}

In this section we investigate the effect of the development of stock markets and the provision of long-term credit on firms ability to finance growth. We adapt a financial planning model to estimate

\footnotetext{
${ }^{15}$ Convenants in long-term debt contracts may contain provisions requiring the firm to maintain a specific ratio of short-term assets to liabilities. In these cases, when the firm fails to maintain sufficient short-term assets, the maturity of long-term debt is shortened.

${ }^{16}$ Inspection of the Table suggests that the associations between sources of financing and uses of funds may be somewhat stronger in developing countries.
} 
for each firm in our sample the rate of growth at which it can be financed internally or by only relying on short-term financing. We then examine how the level of development of financial markets and institutions affects the proportion of firms whose growth exceeds this estimated rate.

The question at issue is whether the underdevelopment of financial markets and institutions prevents firms in some countries from investing in potentially profitable growth opportunities. Such an effect, if it exists, will not constrain all firms equally. Firms that can finance themselves from retained earnings will be minimally affected, whereas the growth of firms whose financing need exceeds their internal resources may be severely constrained. ${ }^{17}$ To gauge the effect of access to financial markets on the firm's ability to exploit growth options, it is necessary to identify firms that have an external financing need and examine whether their realized growth depends on the development of financial markets.

A firm's external financing depends on magnitude of its internal cash flows relative to its investment opportunities. Both the firm's cash flows and its optimal investment level are endogenous and their ratio may systematically differ across countries even for firms employing the same technology. Thus, for example, a firm whose technology is capital intensive may need to finance large investment expenditures in order to grow. However, if the firm has sufficient market power or faces high demand, it may be able to generate sufficient cash flow internally to finance investment, whereas an equivalent firm in a more competitive economy may require external financing to grow at the same rate. Moreover, the level of competition faced by a capital intensive firms may itself depend on the development of financial markets and institutions. In an economy in which financial markets are not well developed new firms may not be able to enter capital intensive industries. As a result, already

\footnotetext{
${ }^{17}$ In this paper we focus on direct effects of access to external financing on firms. Financial market development may spur economic growth and thereby also indirectly affect internally financed firms (see Levine and Zervos (1995)).
} 
established firms in capital intensive industries may earn supernormal profits and be able to finance their growth internally. ${ }^{18}$

To control for this endogeneity, we adapt a financial planning model to estimate for each firm in our sample the maximum rate of growth that can be financed internally or with limited access to the . market for long-term capital. If demand for their products is sufficiently high, firms can grow faster than this maximum constrained rate by obtaining external long-term finance. The proportion of firms that do so depend both on access to financial markets and on the cost of external financing. We test the hypothesis that the less developed the market and financial intermediaries, the higher the cost of external financing, and the lower the proportion of firms that grow faster than this maximum constrained rate.

Our estimate of the firm's constrained growth rate is based on the standard "percentage of sales" approach to financial planning. ${ }^{19}$ This approach makes three simplifying assumptions about relationship between the growth rate of the firm's sales and the need for investment funds. First, the ratio of assets used in production to sales is constant. Thus, the required total investment increases in proportion to the firm's growth in sales. Second, the firm's profit rate per unit of sales is constant. ${ }^{20}$ Three, it is assumed that the economic depreciation of existing assets equals that reported in the financial statements. Given these assumptions, the external financing need at time $t$ of a firm growing at $g_{t}$ per cent a year is given by

$$
\mathrm{EFN}_{\mathrm{t}}=\mathrm{g}_{\mathrm{t}} * \text { Assets }_{\mathrm{t}}-\left(1+\mathrm{g}_{\mathrm{t}}\right) * \text { Earnings }_{\mathrm{t}}^{*} \mathrm{~b}_{\mathrm{t}}
$$

\footnotetext{
${ }^{18}$ Moreover, the capital intensity of an industry depends on the cost of labor and may differ across countries. This reasoning suggests industries that depend on external financing may differ across countries and cannot be identified a priori.

${ }^{19}$ The percentage of sales approach is explained in most introductionary corporate finance texts. For an especially clear presentation, see Ross, Westerfield and Jordan (1995).

${ }^{20}$ This is a strong assumption. Below we provide sensitivity tests that show that our results remain unaffected if we assume that the earnings on marginal sales are lower than on average sales.
} 
where $E F N_{t}$ is the external financing need and $b_{t}$ is the proportion of the firm's earnings that are retained for reinvestment at time t. Earnings are calculated after interest and taxes. The first term on the right-hand side is the required investment for a firm growing at $g_{t}$ percent. The second term is the internally available capital for investment, taking the firm's dividend payout as given. The maximum growth rate which can be financed internally is obtained by equating the $\mathrm{EFN}_{\mathrm{t}}$ to zero and solving this expression for $g_{t}$. This rate, referred to as the "internal growth rate" $I_{G R}$ and is given by

$$
\operatorname{IGR}_{\mathrm{t}}=\left(\mathrm{ROA}_{\mathrm{t}}^{*} \mathrm{~b}_{\mathrm{t}}\right) /\left(1-\mathrm{ROA}_{\mathrm{t}}^{*} \mathrm{~b}_{\mathrm{t}}\right)
$$

where $\mathrm{ROA}_{\mathrm{t}}$ is the firm's return on assets, or the ratio of earnings after taxes and interest to assets.

The $\mathrm{IGR}_{\mathrm{t}}$ is convex and increasing in the firm's return on assets. Thus, more profitable firms can finance higher growth rates internally.

The internal growth rate is an estimate of the maximum growth rate in sales that a firm can finance while relying only on its internal resources and maintaining its dividend. Firms can grow at a faster rate by obtaining short-term or long-term credit, issuing equity or, in general by cutting dividends. Since our focus is on access to long term capital we define two other measures of maximum growth under financing constraints. Our first measure, the maximum short-term financed growth rate, $\mathrm{MSFG}_{\mathfrak{t}}$, is an estimate of the maximum rate of growth of a firm that reinvests all its earnings and obtains enough short-term credit to maintain the ratio of its short-term borrowing to assets. The definition of the $\mathrm{MSFG}_{\mathfrak{t}}$, thus assumes that the firm does not engage in long-term borrowing or sale of equity to finance growth.

The use of the current realized ratio of short-term borrowing to assets to calculate $\mathrm{MSFG}_{\mathrm{t}}$, ensures that the estimate is feasible and does not assume levels of short term credit that are so costly that they would never be chosen by firms. By the same token, the estimate is likely to be conservative, because some firms may have additional short-term borrowing capacity. The estimate of $\mathrm{MSFG}_{\mathfrak{t}}$, is 
obtained by substituting $b_{t}=1$ and by using the value of assets that are not financed by new short-term credit in place of total assets in equation (1). The assets not financed by short-term debt are termed "long-term capital" and obtained by multiplying total assets by one minus the ratio of short-term liabilities to total assets. More specifically, the $\mathrm{MSFG}_{\mathfrak{t}}$ is given by

$$
\mathrm{MSFG}_{\mathrm{t}}=\left(\mathrm{ROLTC}_{\mathrm{t}}\right) /\left(1-\mathrm{ROLTC}_{\mathrm{t}}\right) \text {, }
$$

where ROLTC $_{t}$ is given by the ratio of earnings, after tax and interest, to long-term capital. For brevity we shall refer to a firm growing at rate that exceeds the $\mathrm{MSFG}_{\mathrm{t}}$ as growing at above its "predicted" rate.

Our final estimate of the firm's growth rate is give by the "maximum sustainable growth rate" MSGR $_{\mathrm{t}}$. The MSGR $\mathrm{Mi}_{\mathrm{t}}$ the maximum growth attainable if the firm does not pay dividends and obtains just enough short-term and long-term debt financing to maintain the ratio of total debt to assets constant. Thus, it is implicitly assumed that the firm does not issue equity or increase leverage beyond the realized level.

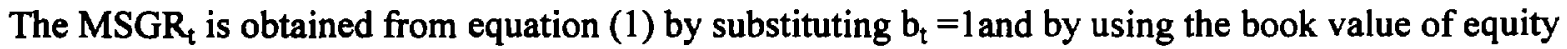
in place of total assets. Setting $\mathrm{EFN}_{\mathrm{t}}$ to zero and solving for the growth rate yields

$$
\operatorname{MSGR}_{\mathbf{t}}=\left(\operatorname{ROE}_{\mathrm{t}}\right) /\left(1-\mathrm{ROE}_{\mathrm{t}}\right)
$$

where $\mathrm{ROE}_{\mathrm{t}}$ is the ratio of net income to equity. ${ }^{21} \mathrm{~A}$ firm's sustainable growth rate depends on its initial leverage.

The three formulas above provide progressively less constrained estimates of the maximum attainable growth rate for each firm. The estimates are conservative in three ways. First, as discussed above, each maximal growth rate assumes firm utilize the unconstrained sources of finance no more

\footnotetext{
${ }^{21}$ For a discussion of practical application see Ross, Westerfield and Jordan (1995).
} 
intensively than it is currently doing. ${ }^{22}$ Accordingly, interpretations of our results below take this into account. Second, firms with spare capacity do not need to invest and may grow at a faster rate than predicted by the financial planning model. We attempt to mitigate the potential problem posed by spare capacity by using each firm's maximal constrained growth rates averaged over the whole sample period in our tests below. Third, the financial planning model abstracts from technical progress that reduces the requirements for investment capital. Thus, it may overstate the cost of growth and underestimate the maximum growth rate attainable using unconstrained sources of finance.

Our empirical tests rely on ratios of contemporaneous earnings and assets and annual growth rates of sales. The annual ratios are averaged over the sample period. We do not compare levels of earnings and stocks of assets over several years. Thus, the variables we use are unlikely to significantly affected by price level changes. ${ }^{23}$

Table 3 presents for each sample country the proportion of firms whose mean annual growth rate of sales exceeds the means of the three maximal constrained growth rates discussed above. Column 1 provides an estimate of the proportion of firms that grow faster than our estimate of the maximal growth rate compatible with maintaining their dividend payout ratio and relying only on internal financing. Column 2 shows the proportion of firms whose growth rates exceed the estimate of their maximal growth rate that can be financed by relying only on internal and short-term finance, as defined above. Column 3 shows the proportion of firms in each country whose realized growth rate

\footnotetext{
${ }^{22}$ The assumption in the calculation of MSGR, that the firm maintains its current leverage ensures that MSGR, is feasible.

${ }^{23}$ In the two highest inflation countries, Brazil and Mexico, firms financial statements are adjsuted for changes in the price level. In other countries, the stated value of the firms long-term assets may be lower than than their replacement cost. In the regressions below, we include an inflation variable to detect possible misspecific ations and present estimates in which the dependent variable is corrected for within year inflation. There is no indication that price level changes are producing significant misspecifications.
} 
exceeds the maximum rate compatible with the maintenance of their leverage ratio and reliance on retained earnings for infusions of equity capital.

Inspection of column 1 shows that in most countries a majority of firms grow at rates that exceed those that can be internally financed while maintaining their dividend payouts. Thus, the majority of firms in most countries require some form of external financing. The exceptions are Brazil and South Africa, where almost two thirds of the firms grow at rates at which they can self-finance. At the other extreme are Thailand, Japan and Korea, where approximately two thirds of the firms require outside financing. For most countries between $40-50 \%$ would be a conservative estimate of the proportion of firms whose supply of investment capital does not directly depend on external finance and the development of financial markets. ${ }^{24}$ Column 2 shows the majority of firms in most countries can finance their realized growth using conventional amounts of short-term financing. The exceptions are again are Japan, Korea, and Thailand and also Singapore.

By comparing across columns it is possible to obtain a rough indication of the relative importance of long-term and short-term debt in providing capital for growth. Inspection of the table reveals that in most countries short-term credit appears to be more important than long-term credit in relaxing financing constraints on the growth of firms in the industry. In only five countries, Canada, Germany, Finland, Korea and Norway, does long-term debt play a greater role than short-term debt in providing resources for growth.

Developing countries in our sample fall into one of three rough categories. In the two countries with the highest inflation rates, Brazil and Mexico, neither long-term nor short-term credit is of

\footnotetext{
${ }^{24}$ Note that while a firm may be able to finance its desired growth rate internally, it may not be optimal to do so. Thus, for example, in some tax regimes a firm may increase value by issuing debt to repurchase stock in order to take advantage of interest tax-shields. In the absence of well functioning banks or financial intermediaries, the firm may not be able to fully utilize available tax shields. However, while this may be a private cost for the firm, it is not necessarily an economic cost for the country.
} 
importance in relaxing the constraints on firm growth. ${ }^{25}$ In some other developing countries such as Jordan, Malaysia, South Africa, Turkey and Zimbabwe, short-term credit is relatively more important than long-term credit. Finally, there is a group including India, Korea, Pakistan and Thailand where the relative contributions of long-term and short-term credit to growth are similar to those in the developed economies.

The comparison of India with Italy is particularly instructive. More Indian than Italian firms are growing at rates that exceed those that could be self-financed. As expected, most of the difference is accounted for by greater use of short-term debt in India. However, the role of long-term debt and equity is comparable between the two countries.

We next describe the characteristics of externally financed firms in each country. For each firm we calculate the proportion of years in which its growth rate in the sample period exceeds its predicted growth rate. For each country we regress this variable on firm characteristics. The results are presented in Table 4 . Since there is no formal model linking firm characteristics to the external financing need, the regression coefficients should be interpreted as providing descriptive partial correlations rather than estimates of a model.

Inspection of the table reveals that less profitable firms are more likely to grow at rates that require the firm to obtain long-term credit or equity (In twenty of the cases the coefficients are negative and significant at $10 \%$ level or better. Only in the case of Zimbabwe are more profitable firms more likely to require external financing). In fourteen of the cases there is a significant positive association between the level of investment and reliance on external long-term capital.

The associations between growth at rates that exceed the predicted rate and the other firm-specific variables show more variation across countries. For example, in Canada, UK and US large firms tend

\footnotetext{
${ }^{25}$ This result is consistent with Demirgüç-Kunt and Maksimovic (1996) finding on the financing choices of Brazilian and Mexican firms.
} 
to grow at rates that could be financed without access to long-term credit or to the stock market. In Mexico, large size is associated with rates of growth that require long-term credit or equity. ${ }^{26}$

In seven countries, including Canada, Germany, Japan, UK and US, high dividends are associated with rates of growth below the predicted rate. In several countries there is no association, suggesting that some firms may be maintaining dividends in preference to reducing their long-term borrowing or equity financing. ${ }^{27}$

In five countries, again including Canada, Japan and US, there is a significant negative association between ratio of fixed assets to total assets and rates of growth that exceed the predicted rate. This association is consistent with the result in the previous section that external financing is correlated with investment in short-term assets. It may also reflect the industry composition and demand patterns in these countries. The final firm-specific variable, sales to total assets, is not related to the probability that the firm is growing at a rate that exceeds the predicted rate.

We next examine how the proportion of firms in each county whose growth exceeds the predicted rate depends on the development of financial markets and institution. We test the hypothesis that the more developed the market, the greater the proportion of firms able to grow at rates in excess of the predicted rate.

\footnotetext{
${ }^{26}$ Interestingly, the association between firm size and growth in excess of MSGRt is stronger than this association. This is because the calculation of MSGR takes into account the firms existing ratio of long-term debt to equity. Thus, in countries where using the probability of growth at rates above MSGR as the dependent variable, the coefficient of the size variable, TAGDP, is statistically significant in twelve cases our of thirty. Of the ten developing countries, it is positive and significant in five and negative and significant in one. By contrast. of the twenty developed countries it is negative and significant in five and positive and significant in only one. This pattern suggests that in developing countries equity financing and high levels of long-term credit finance the growth of large firms, whereas in developed countries they tend to provide growth capital to small firms. Note that this does not imply that large firms in developed countries do not issue equity or have high leverage, only that these forms of financing is not as likely to be strictly necessary to permit growth.

${ }^{27}$ This association are stronger when the dependent variable is MSGR. The coefficient of DIVTA is negative and significant in 19 of the 29 cases.
} 
In our regressions the development of stock markets is measured by the ratio of market capitalization to Gross Domestic Product (MCAP/GDP) and a measure of market activity, the stock market turnover ratio in each economy (TOR). Both variables have been found useful indicators of market development by Demirgüç-Kunt and Levine (1995). The size of the banking sector is measured by the ratio of the assets of deposit banks to the Gross Domestic Product (BANK/GDP).

We use an indicator of the ease with which firms can enter into long-term contracts. The law and order variable is a commercially available index of experts' evaluations of the adherence to legal norms within each country, shown in Table 1 . High levels of the index denote greater reliance on the legal system to mediate disputes. The index is a good predictor of use of long-term debt by large firms in cross-country study of financial structures (Demirgüç-Kunt and Maksimovic (1996a)). Finally, a firm-specific descriptor, the mean ratio of long-term debt to total assets of the firms in each country, provides a direct measure of the utilization of long-term debt.

Three variables describe the economic environment of each country. We control for economy-wide, as opposed to firm-specific, growth opportunities by the growth rate of the real Gross Domestic Product per capita. We use the rate of inflation below to adjust for price level changes and, in the regressions, as a control variable to detect possible biases resulting from price level changes. ${ }^{28}$ The ratio of government subsidies to Gross Domestic Product is an indicator of government intervention in the economy. The government both provides direct funding to firms and acts as an implicit or explicit guarantor of loans. Table 5 contains summary statistics for the descriptors for the economy and firm specific characteristics used in the regressions reported below.

\footnotetext{
${ }^{28}$ The rate of inflation is highly correlated with the variance of the inflation rate. Thus, the rate of inflation may also be a proxy for the costs of entering into long-term financing contracts.
} 
Our statistical model follows the cross-sectional approach used in the growth literature. ${ }^{29}$ In Table 6 , the proportion of firms in each country whose mean annual growth rate in the sample period exceeded their mean annual predicted growth rate is regressed on the means of the market and institutional indicators and firm characteristics in each country. ${ }^{30}$ Our first specification in column (1) is an OLS regression that includes only market and institutional indicators and the macroeconomic control variables. In column (2) we augment the specification to include firm-specific descriptors. In columns (3) to (5) we retain only the statistically significant firm descriptors and vary the specification to explore the role of two explanatory variables of particular interest.

Our two macro-economic control variables are the mean rate of growth of the economy and the mean rate of inflation. The higher the economy-wide growth rate, the greater the firm's desire to grow at a rate that exceeds its predicted rate. We include the mean rate of inflation in each country to control for the possibility that there may be a systematic bias in the estimate of MSFG caused by inflation. As predicted, in all the specifications reported in the table the coefficient of economic growth is positive and significant at the $1 \%$ level. The coefficient of inflation is only significant, at the $10 \%$ level, in specification (2), indicating that systematic biases due to differences in inflation across countries are unlikely to be influencing the results. ${ }^{31}$

Two variables measure the development and effectiveness of stock markets. One of these, the turnover ratio is positive and highly significant in all specifications. The market capitalization ratio is not significant in any specification. Thus, an active stock market facilitates the relaxation of financing constraints. Market capitalization, by itself, does not affect the growth of firms. The

\footnotetext{
${ }^{29}$ This statistical specification takes into account that the questions addressed are cross-sectional and that longterm financing is likely to be responsive to permanent rather than transitory changes in the institutions. A panel approach would give equal weights to time-series and cross-sectional effects.

${ }^{30}$ We do not have government subsidy data for Hong Kong, Jordan, South Africa, and Zimbabwe. In addition, dividend data are not available for Mexico. However excluding these variables from the analysis to expand the sample size to full 30 countries does not significantly alter the rest of the results.

${ }^{31}$ We also discuss inflation adjustment and present estimates using a specific adjustment below.
} 
coefficient of the law and order variable is significant and positive in every specification in which it is included and in which the mean ratio of long-term debt to total assets is excluded. We interpret this to indicate that a high degree of adherence to legal norms facilitates long-term contracts between creditors and firms. When the ratio of long-term debt to total assets is included by itself its coefficient is positive and significant. With both variables included, the coefficient of the ratio of long-term debt to total assets loses significance, but remains significant at the $101 \%$ level. However, the coefficient of the law and order index loses significance. This pattern indicates that there is a positive and significant link between the quantity of long-term debt outstanding and the growth rate of firms. The pattern also supports the interpretation of the law and order index as an indicator of the ability to contract. Demirgüç-Kunt and Maksimovic (1996b), found that high values of this index were associated with higher levels of long-term debt. The new result shows that the effect of legal institutions on the ability to raise financing affects firms' abilities to invest and grow.

The final institutional variable is the ratio of government subsidies to the gross domestic product. We find no evidence that subsidies promote growth of firms in general. There is a negative relationship between the level of subsidies and the proportion of firms growing at rates in excess of those that can be financed internally and by realized levels of short-term debt. This evidence is consistent with several hypotheses about the role of subsidies. They may divert resources from firms in general to a smaller number of targeted firms. The level of subsidies may also be an indicator of more generalized intervention that reduces transfers of capital.

In the last specification in Table 6 we explore the relationship between government subsidies and long-term debt in more detail. Of particular interest is the effect of government subsidies that are provided in the form of directed long-term credit. Although no data on directed long-term credit is available, an estimate may be obtained if it is assumed that the proportion of long-term debt that consists of directed credit is higher in countries where government subsidies are higher. To capture 
this effect, in specification (6) we drop the government subsidy variable and replace it by a variable that interacts government subsidies and our long-term debt variable. The coefficient of the interacted variable is negative and significant. This result indicates that although long term debt has a positive effect on growth, to the extent this credit is directed or government subsidized, it results in a negative effect.

Two of the firm-specific descriptors are also consistently statistically significant. Capital intensive firms are more likely to grow at rates that require long-term external financing than firms that do not invest significantly in fixed assets. Interestingly, high-profits are associated with growth rates that do not exceed the predicted rate. When controlling for institutional and market development, we do not find significant associations between long-term external financing and the mean level of investment, average firm-size, the dividends paid out by firms and the ratio of sales to assets.

\section{ROBUSTNESS TESTS}

We have performed several checks on the robustness of the principal results reported in Section 3. In the first test we check the consistency of the results when extreme observations are dropped and the estimations are repeated. We have also recomputed the firms' predicted growth rates under alternative assumptions about the profits from marginal sales and used these new predicted rates in estimations. We have repeated the main analysis of Section 3 using an alternative definition of firm growth. Finally, we have reestimated the reported regressions after making a within-year inflation adjustment on the dependent variable.

\subsection{Outlier Analysis}


The specifications in Table 6 were repeated, dropping outliers for specific variables. Since the number of observations is small, this procedure was performed serially: the countries with extreme values of a variable were omitted from the estimations when that specific variable was analyzed, and were included in the sample when subsequent variables were analyzed. In each case the aim was to exclude obvious outliers. Hence, the number of countries dropped in each test depends on the particular variable.

In the first outlier test we dropped the three countries with the highest rates of inflation: Brazil, Mexico and Turkey. Subsequent tests involved dropping the country with the highest stock-market turnover ratio (Germany), countries whose economies were not growing (Jordan and South Africa), countries in which the fewest firms grew at a rate exceeding the predicted rate (South Africa and Turkey) and the country with the greatest government subsidies as a proportion Gross Domestic Product (Brazil). The results were not affected when these countries were dropped from the analysis.

\subsection{Predicted Growth and the Profits on Marginal Income}

The growth estimates used in the above regressions were based on the assumption that the firm's profit rate on marginal sales equals its average profit rate. Thus, revenues from new growth are assumed to provide as much resources for investment as sales to established customers. To test whether this assumption is critical to our findings we generalize the estimates of maximal internally financed growth to allow a lower rate of earnings on new growth. Specifically, we modify the financial planning model by introducing a parameter $\mathrm{z}$ that measures the ratio of the profit rate on the new sales to the firm's average profits rate. Thus, the modified predicted rate is now given by

$$
\text { MSFG }_{t}=\left(\text { ROLTC }_{t}\right) /\left(1-z^{*} \text { ROLTC }_{t}\right)
$$

As a sensitivity check we have reestimated specifications in Table 6 for $z=0,0.25,0.5$ and 0.75 . Our conclusions remain unchanged. Table 7 presents a sample specification, specification (3) for the 
given values of $\mathbf{z}$. As inspection of the table reveals, the assumption that marginal earnings equal average earnings is not critical for our results.

\subsection{Asset Growth and Inflation Adjustment}

The financial planning model on which the tests are based assumes an equivalence between the rates at which firms' assets and sales grow. Thus far, the definition of firm growth used in the empirical tests has been is that of growth in sales. As a specification test, we have reestimated the regression equations in Table 6 using, as the dependent variable, the proportion of the firms whose growth in assets exceeds the predicted rate. Our principal results remain unaffected. A sample regression is shown in Table 8. Column (1) of Table 8 repeats specification (3) of Table 6, in which the dependent variable is the proportion of firms whose realized growth rate in sales exceeds the predicted rate. The realized growth rate of assets is used to form the dependent variable replacing realized growth rate of sales in column (2) of Table 8. There are two differences between the results reported in columns (1) and (2). One of the firm-specific variables, the ratio of fixed assets to total assets, loses significance. The coefficient of the ratio of government subsidies to Gross Domestic Product, which is not significant in column (1), becomes significant in column (2). However, this is not a new result, in that this variable is significant under alternative specifications in Table 6.

The variables used in the regressions are derived from accounting data, and except in the case of Brazil and Mexico, are based on historical acquisition costs. In periods of inflation, historical costs may not reflect with sufficient accuracy the value of the firm's assets. As a sensitivity test, we have reestimated the regressions using an adjustment for the effect of inflation on firms' assets and earnings. Since we use ratios and do not use time-series of levels data, we adjust for inflation that occurs within any year so that the firm's total assets and earnings at the beginning and the end of a 
year can be compared. Thus, the value of the firm's total assets required to support sales at time $t+1$ in time $t$ dollars is given by

$$
\left(\left(\mathrm{TA}_{\mathrm{t}+1} /(1+\pi)\right)+(\pi /(1+\pi))^{*}\left(\mathrm{TA}_{\mathrm{t}}-\mathrm{DEP}_{\mathrm{t}+1}\right)\right.
$$

where $\pi$ is the rate of inflation between time $t$ and $t+1$ and $D D E P_{t}$ is the depreciation of the firm's long-term assets between $t$ and $t+1$. The second term is an adjustment for the fact that the firm's undepreciated assets continue on the firm's books at historical cost. Similarly, the firms earnings between time $t$ and $t+1$ are reduced by $\pi$ times $D P_{t+1}$ to account for the fact that the replacement value of assets is higher than their historical cost.

When the regressions in Table 6 are reestimated using the inflation adjusted data and the growth of sales as the relevant growth rate we obtain results for the stock-market and legal variables similar to those reported in the table. The major difference is that now the ratio of the size of the banking sector to Gross Domestic Product is positive and significant and that the firm profit variable switches signs. A sample equation is shown in the column (3) of Table 8, where the equation reported in column (3) of Table 6 is reestimated using inflation adjusted data.

\section{CONCLUSION}

In this paper we investigate two issues. First, we examine whether there are similarities across countries in the ways firms finance long-term and short-term investment. Second, we investigate whether specific differences in financial systems and legal institutions constrain firms to grow at rates no greater than they could attain by relying on their internal resources or short-term borrowing.

For a sample of thirty developing and developed countries, we examine the sources of capital that firms use when they invest in fixed assets, such as plants and equipment, and short-term assets, such as inventories and credit offered to customers. Most firms in our sample used internal funds to finance fixed investment and externally raised funds, especially short-term debt, but also long-term 
debt and equity, to finance short-term investment. Thus, external financing may not primarily be used to finance long-term investment directly, but to finance more liquid, short-term assets, thereby freeing up capital that the firm can redeploy. This pattern of financing holds for almost every country in our sample, both developed and developing. The pattern suggests that conflicts of interest that naturally arise between creditors and borrowers are more severe when external funds are used to fund long-term assets.

To investigate the relationship between financial institutions and markets we estimate for each firm our sample a predicted rate at which it can grow if it relies on retained earnings and short-term credit only. We show that the proportion of firms that grow at rates exceeding this predicted rate in each country is associated with specific feature of the legal system, financial markets and institutions.

Our results show that both stock market and the development of legal institutions are important in facilitating firm growth. Firms in countries which have active stock markets and high ratings for compliance with legal norms were able to obtain external funds and grow faster. High compliance with legal norms is strongly associated with the use of long-term credit by firms. These findings are robust and provide firm-level support for the proposition that the development of financial markets and institutions facilitates economic growth., advanced by King and Levine (1993) and Levine and Zervos (1995). Consistent with Levine and Zervos (1995), we find the size of the stock market by itself is not as important in mobilizing finance as the level of activity of the market.

In our sample, we find no evidence that government subsidies to firms are associated with increases in the number of firms growing at rates that exceed the predicted rate. Government subsidies do not appear to have promoted economic environments in which firms obtain resources for financing growth from financial markets. To the contrary, our evidence indicates that although long term credit 
is associated with greater numbers of firms growing at higher than predicted rates, in economies where government subsidized this result is reversed.

The relationship between external financing and the composition of investment has two policy implications for promoting investment and growth. First, the fact that, even in countries with well developed financial systems, external financing is more strongly associated with short-term assets suggests that government programs that fund long-term investment directly are unlikely to be fully successful if they rely on standard financial contracts and standard means of enforcement. Second, to the extent that conflicts of interest between borrowers and creditors prevent effective contracting between the parties, it is necessary to reconsider the implications of government policies that affect earnings of firms on long-term investment. For example, subsidies that maintain an inefficient firm in operation may reduce the earnings of its efficient competitors, making it difficult for them to finance unrelated projects. Likewise, policies that permit increased competition from imports may have an adverse effect on investment unless accompanied by development of financial markets. 


\section{REFERENCES}

Allen, F., 1993, Stock markets and resource allocation, in Mayer, C. and X. Vives, (eds.), Capital Markets and Financial Intermediation, Cambridge University Press.

Demirgüç-Kunt, A. and Levine, 1996, Stock market development and financial intermediaries: stylized facts, World Bank Economic Review, Vol 10, No.2.

Demirgüç-Kunt, A. and V. Maksimovic, 1996a, Institutions, Financial Markets And Firm Debt Maturity, World Bank mimeo.

Demirgüç-Kunt, A. and V. Maksimovic, 1996b, Stock Market Development and Firms' Financing Choices, World Bank Economic Review, Vol 10, No.2.

Diamond, D.W., 1996, Liquidity, banks and markets, Policy Research Working Paper No 1566, The World Bank.

Diamond, D.W.., 1993, Bank Loan Maturity and Priority When Borrowers Can Refinance, in Mayer, C. and X. Vives, (eds.), Capital Markets and Financial Intermediation, Cambridge University Press.

Fazzari, S.M., Hubbard, R. G. and B.C. Petersen, 1988, Financing Constraints and Corporate Investment, Brookings Papers on Economic Activity 0, 141-95.

Fischer, S., 1989, The Effect of the Stock Market on Investment:A Comparative Study: Comment, European Economic Review 33, 956-59.

Fitzgerald, R.D., Stickler A.D. and T.R. Watts, 1979, International survey of accounting principles and reporting practices, Price Waterhouse International, distributed by Butterworths, Ontario, Canada.

Grossman, S.J., 1976, On the Efficiency of Competitive Stock Markets Where Trades Have Diverse Information. Journal of Finance 31, 573-85.

Grossman, S.J. and Stiglitz, J.E., 1980, On the Impossibility of Informationally Efficient Markets, American Economic Review 70, 393-408.

Hamada, K., 1989, The Effect of the Stock Market on Investment: A Comparative Study: Comment, European Economic Review 33, 959-61.

Holmstrom, B. and J. Tirole, 1993, Market Liquidity and Performance Monitoring, Journal of Political Economy 101, 678-709.

Jensen M. and W. Meckling, 1976, Theory of the Firm: Managerial Behavior, Agency Costs, and Capital Structure, Journal of Financial Economics, 3, 305-360.

Kane, E.J., 1989, The S\&L Insurance Mess: How did it Happen? Washington, D.C: Urban Institute Press.

Kaplan, S. and L. Zingales, 1996, Do Investment-Cashflow Sensitivities Provide Useful Measures of Financing Constraints, University of Chicago Working Paper.

King, R. and R. Levine, 1993, Finance and Growth: Schumpeter Might be Right, Quarterly Journal of Economics, 108(3), pp.717-738.

Knack, S., and P. Keefer, 1995, Institutions and Economic Performance: Cross-country Tests Using Alternative Institutional Measures, Economics and Politics 7, 207-227. 
Levine R. and S. Zervos, 1995, Stock Markets, Banks, and Economic Growth, World Bank mimeo.

Modigliani, F. and M. Miller, 1958, The Cost of Capital, Corporation finance, and the Theory of Investment, American Economic Review, 48, 261-297.

Morck, R, Shleifer, A, and R..W. Vishny, 1990, The Stock Market and Investment: Is the Market a Sideshow? Brookings Papers on Economic Activity 0, 157-202.

Mullins, M, and S.B. Wadhwani, 1989, The Effect of the Stock Market on Investment: A Comparative Study, European Economic Review 33, 939-56.

Myers,S.C. 1977, Determinants of Corporate Borrowing, Journal of Financial Economics 5, $147-$ 175.

Myers, S.C. and N.S. Majluf, 1984, Corporate Financing and Investment Decisions When Firms Have Information That Investors Do Not Have, Journal of Financial Economics, 187-221.

Price Waterhouse, 1993, Doing Business in Turkey, (Price Waterhouse, Istanbul, Turkey).

Rajan, R. and L. Zingales, 1996, Financial Dependence and Growth, mimeo.

Rajan, R. and L. Zingales, 1995, Is there an optimal capital structure? Some Evidence from international data, Journal of Finance.

Ross, S.A., Westerfield R.W. and B.D. Jordan, 1995, Fundamentals of Corporate Finance, Chicago: Richard D. Irwin.

Shleifer, A., 1994, Establishing Property Rights, Proceedings of the World Bank Conference on Development Economics, World Bank Economic Review 8, 93-117.

Shleifer, A. and R. W. Vishny, 1992, Liquidation Values and Debt Capacity: A Market Equilibrium Approach, Journal of Finance 47(4), 1343-1365.

Stiglitz J. and A. Weiss, 1981, Credit Rationing in Markets with Imperfect Information, American Economic Review, 71, 393-410.

Williamson, O.E., 1994, The Institutions and Governance of Economic Development and Reform, Proceedings of the World Bank Conference on Development Economics, World Bank Economic Review 8, 171-197.

Williamson, O.E., 1988, Corporate Finance and Corporate Governance, Journal of Finance 43, 56791. 


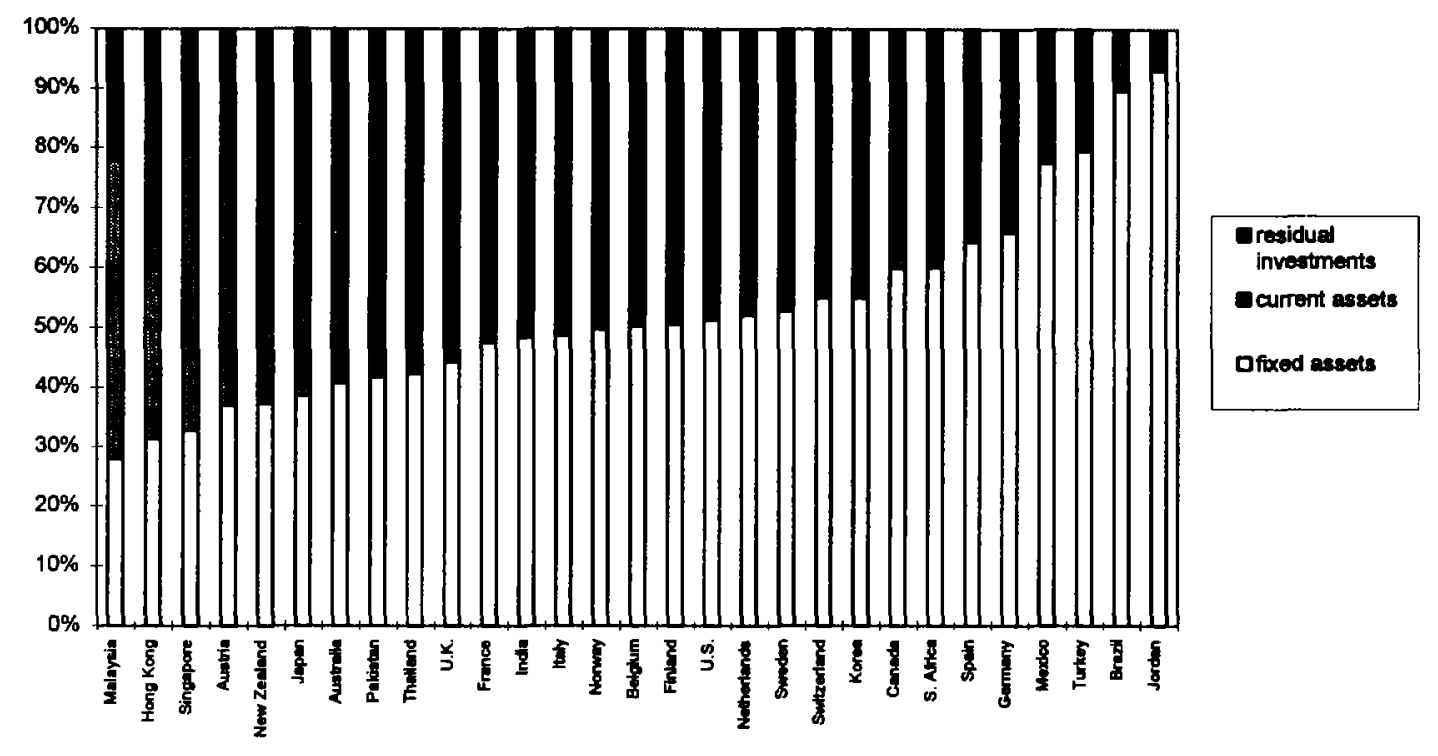

Figure 1. How do corporations invest? The figure presents the mean proportions of total annual gross investment accounted for by current assets, fixed assets and residual investments in the period 1980-1991. Current assets are assets with maturity less than or equal to one year. Fixed assets consist of plant and equipment. The residual category consists of assets whose maturity is greater than a year but are not fixed assets, such as trademarks and patents purchased by the firm or investment holding in other firms. The countries in the figure are ordered by the proportion of their investment in fixed assets. 


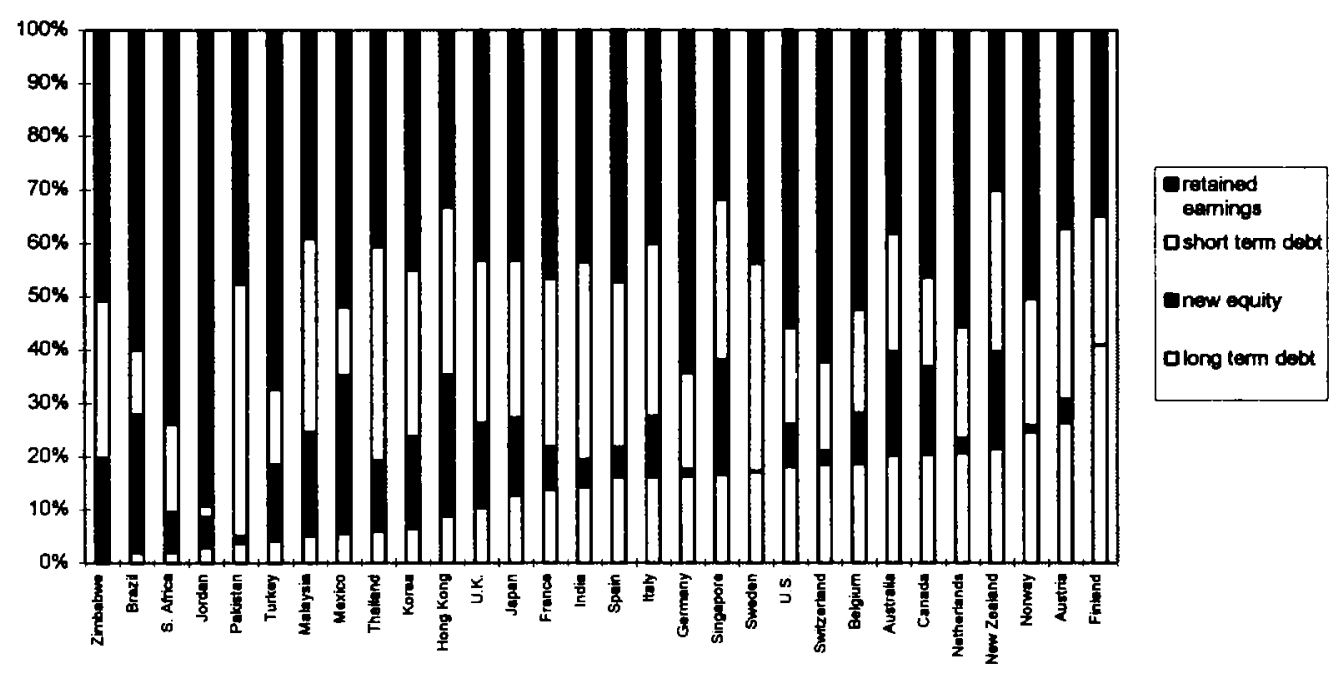

Figure 2. How do corporations finance investment? The figure presents the mean proportions of total gross investment financed by short-term debt, long-term debt, newly issued capital and cash flow from operations in the period 1980-1991. Short-term debt is defined as current liabilities, with maturity less than or equal to one year. Long-term debt are liabilities with maturity greater than one year. Cash flow from operations is defined as the sum of earnings after taxes, less dividends, plus depreciation. Newly issued capital includes all increases in the firm's equity resulting from public offerings, private placements, conversions of convertible securities and exchanges for assets of other businesses. The countries in the figure are ordered by the proportion of their investment financed by long-term debt. 
Table I

Economic and Institutional Indicators

GDP/CAP is the real GDP per capita in US\$ in 1991. Growth rate is the average annual growth rate in GDP/CAP for the period 1980-91. Average annual inflation is given for the period 1980-91. Law and order indicator is scored 0-6. It reflects the degree to which the citizens of a country are willing to accept the established institutions to make and implement laws and adjudicate disputes. Higher scores indicate sound political institutions and a strong court system. Lower scores indicate a tradition of depending on physical force or illegal means to settle claims. Values reported are 1985-91 averages. Govemment subsidies are defined as grants on current account by the public authorities to (i) private industries and public corporations and (ii) government enterprises. The figures are as percent of GDP averaged over 1983-1991.

\begin{tabular}{|c|c|c|c|c|c|}
\hline & $\begin{array}{l}\text { GDP/CAP } \\
\text { (US \$) }\end{array}$ & $\begin{array}{l}\text { Growth 80-91 } \\
\text { (percent) }\end{array}$ & $\begin{array}{l}\text { Inflation } 80-91 \\
\text { (percent) }\end{array}$ & $\begin{array}{l}\text { Law and Order } \\
\text { lndicator } \\
1985-91\end{array}$ & $\begin{array}{l}\text { Government } \\
\text { subsidies to private } \\
\text { and public } \\
\text { enterprises } 83-91\end{array}$ \\
\hline Switzerland & 27,492 & 1.7 & 3.8 & 6 & 1.4 \\
\hline Japan & 23,584 & 3.9 & 1.5 & 5 & 0.6 \\
\hline Norway & 19,664 & 1.7 & 5.2 & 6 & 5.9 \\
\hline Sweden & 19,649 & 1.6 & 7.4 & 6 & 4.8 \\
\hline United States & 18,972 & 1.9 & 4.2 & 6 & 0.6 \\
\hline Finland & 18,046 & 1.6 & 6.6 & 6 & 3.0 \\
\hline France & 17,365 & 1.8 & 5.7 & 5 & 2.4 \\
\hline Austria & 17,288 & 2.2 & 3.6 & 6 & 1.3 \\
\hline Netherlands & 16,479 & 2.3 & 1.8 & 6 & 2.6 \\
\hline Germany & 16,439 & 1.8 & 2.8 & 5.5 & 2.0 \\
\hline Canada & 16,098 & 2.0 & 4.3 & 6 & 1.9 \\
\hline Belgium & 16,051 & 2.2 & 4.2 & 6 & 3.5 \\
\hline Italy & 14,570 & 2.5 & 9.5 & 5 & 2.9 \\
\hline Australia & 13,095 & 1.6 & 7.0 & 6 & 3.0 \\
\hline United Kingdom & 12,585 & 2.3 & 5.8 & 4.5 & 1.5 \\
\hline New Zealand & 10,643 & 1.0 & 10.3 & 6 & 1.2 \\
\hline Singapore & 10,294 & 4.9 & 1.9 & 5 & 1.9 \\
\hline Hong Kong & 9,820 & 5.8 & 7.5 & 5 & n.a. \\
\hline Spain & 8,752 & 3.3 & 8.9 & 4 & 2.4 \\
\hline Korea & 4,259 & 6.8 & 5.6 & 2 & 6.3 \\
\hline Malaysia & 2,465 & 3.6 & 1.7 & 4 & 4.6 \\
\hline South Africa & 2,198 & -1.0 & 14.4 & 2 & n.a. \\
\hline Brazil & 2,073 & 2.1 & 327.6 & 4 & 10.7 \\
\hline Mexico & 1,801 & 1.0 & 66.5 & 3 & 2.3 \\
\hline Turkey & 1,375 & 3.1 & 44.7 & 2.5 & 2.2 \\
\hline Jordan & 1,372 & -2.1 & 1.6 & 2 & n.a. \\
\hline Thailand & 1,362 & 7.0 & 3.7 & 3.5 & 1.4 \\
\hline Zimbabwe & 630 & 1.7 & 12.5 & 2 & n.a. \\
\hline India & 375 & 3.3 & 8.2 & 2 & 5.8 \\
\hline Pakistan & 359 & 3.9 & 7.0 & 2 & 5.4 \\
\hline
\end{tabular}




\section{Table II}

\section{How Do Firms Finance Long Term and Short Term Investment?}

The estimates $\left(\beta_{1}, \beta_{2}, \beta_{3}\right)$ are obtained from cross-sectional regressions of firm level data using OLS. For each firm the variables are constructed annually and then averaged over the sample period so that each firm has one observation. PERINV and PERCA are the proportion of firm's investment in fixed and current assets, respectively. PERLTD, PERSTD and PEREQ are the proportions of investment the firm finances by long-term debt, short-term debt and newly issued capital. The last three columns report the differences in the size of the coefficient estimates.

\begin{tabular}{|c|c|c|c|c|c|c|}
\hline \multicolumn{7}{|c|}{ PERINV $_{[\mathrm{Fim}=\mathrm{i}]}=\alpha+\beta_{1}$ PERLTD $_{i}+\beta_{2}$ PERSTD $_{i}+\beta_{3}$ PEREQ $_{i}+\varepsilon$} \\
\hline & $\beta_{1}$ & $\beta_{2}$ & $\beta_{3}$ & $\beta_{1}-\beta_{3}$ & $\beta_{2}-\beta_{3}$ & $\boldsymbol{\beta}_{1}-\boldsymbol{\beta}_{2}$ \\
\hline Australia & $-.113^{*}$ & $-.243^{* * *}$ & $-.209 * * *$ & .096 & -.034 & $.130^{* *}$ \\
\hline Austria & -.305 & $-.740^{* * *}$ & $-.586^{* * *}$ & $.281^{*}$ & -.154 & $.435^{* *}$ \\
\hline Belgium & $-.266 * *$ & $-.368^{* * *}$ & $-.181^{* *}$ & -.085 & $-.187^{*}$ & .102 \\
\hline Brazil & -.219 & $-.820 * * *$ & $-.167^{* * *}$ & -.052 & $-.653^{* * *}$ & $.601 * * *$ \\
\hline Canada & $-.293^{* * *}$ & $-.451^{* * *}$ & $-.451^{* * *}$ & $.158 * *$ & .000 & $.158^{* * *}$ \\
\hline Switzerland & $-.675^{* * *}$ & $-.806^{* * * *}$ & $-.648 * * *$ & -.027 & $-.158 *$ & .131 \\
\hline Germany & $-.564^{* * *}$ & $-.653^{* * *}$ & $-.366^{* * * *}$ & $-.198 * * *$ & $-.287 * * *$ & $.089 * *$ \\
\hline Spain & $-.307 * * *$ & $-.346^{* * *}$ & $-.291 * * *$ & -.017 & -.055 & .039 \\
\hline Finland & $-.503^{* * *}$ & $-.683^{* * * *}$ & .001 & $-.504^{* * * *}$ & $-.683^{* 0 *}$ & .179 \\
\hline France & $-.569 * * 4$ & $-.554^{* * *}$ & $-.387^{* \ldots *}$ & $-.182^{* * *}$ & $-.168 * * *$ & -.014 \\
\hline U.K. & $-.377^{* * * 4}$ & $-.483 * * *$ & $-.418 * * *$ & .041 & $-.065^{* *}$ & $.107^{* * *}$ \\
\hline Hong Kong & $-.343^{* * 4}$ & -.058 & -.147 & $-.196^{*}$ & .089 & $-.286^{* *}$ \\
\hline India & $-.192 * *$ & $-.478^{* * * *}$ & -.169 & -.023 & $-.309 * * *$ & $.286 * * *$ \\
\hline Italy & $-.320 * * n$ & $-.699 * * *$ & -.100 & -.221 & $-.600 * * *$ & $.379 * * *$ \\
\hline Japan & $-.551 * * * 4$ & $-.702 * * *$ & $-.493 * * *$ & -.058 & $-.209 * \cdots$ & $.151^{* * * *}$ \\
\hline Korea & $-.577^{* * * *}$ & $-.565^{* * 4 *}$ & $-.556 * 4 *$ & -.021 & -.008 & -.013 \\
\hline Mexico & $-.180^{*}$ & $-.685^{* * *}$ & $-.135^{* *}$ & -.045 & $-.550 * * *$ & $.505^{* * *}$ \\
\hline Malaysia & .078 & $-.254^{* * * *}$ & .060 & .018 & $-.314^{* * *}$ & $.332 * * *$ \\
\hline Netherlands & $-.145^{* * *}$ & $-.904 * * *$ & $-.558 * * *$ & $.413^{* * *}$ & $-.345^{* * *}$ & $.758 * * *$ \\
\hline Norway & $-.620 * * *$ & $-.786^{* * *}$ & -.003 & $-616^{* * *}$ & $-.782^{* * *}$ & .166 \\
\hline New Zealand & $-1.093 * * *$ & $-1.093^{* * *}$ & $-1.778 * * *$ & $.684^{* * *}$ & $.685^{* * *}$ & .000 \\
\hline Pakistan & $-.436 * * *$ & $-.546^{\circ * *}$ & -.059 & $-.377^{* * *}$ & $-.487^{* * *}$ & .110 \\
\hline Singapore & $.248 * * *$ & -.110 & $.491^{* * *}$ & $-.243^{* *}$ & $-.602^{* * *}$ & $.358^{* * *}$ \\
\hline Sweden & .077 & $-.333 * * *$ & $-.217^{*}$ & $.294 * * *$ & -.116 & $.410^{* * * *}$ \\
\hline Thailand & $-.295^{* * * *}$ & $-.210^{* * *}$ & -.013 & $-.282^{* * *}$ & $-.197^{* *}$ & -.085 \\
\hline Turkey & .112 & -.195 & .247 & -.135 &. .442 & .307 \\
\hline U.S. & $-.262^{* * * 4}$ & $-.437^{* * *}$ & $-.299 * * *$ & $.037^{* *}$ & $-.138^{* * *}$ & $.175^{* * *}$ \\
\hline S. Africa & -.133 & $-.223^{* * *}$ & -.173 & .040 & -.051 & .091 \\
\hline
\end{tabular}

***;* and * indicate statistical significance at 1,5 , and 10 percent levels, respectively. 
Panel B: Short Term Investment

\begin{tabular}{|c|c|c|c|c|c|c|}
\hline & $\beta_{1}$ & $\beta_{2}$ & $\beta_{3}$ & $\beta_{1}-\beta_{3}$ & $\beta_{2}-\beta_{3}$ & $\boldsymbol{\beta}_{1}-\boldsymbol{\beta}_{2}$ \\
\hline Australia & $.124^{\circ}$ & $.446^{* * * 6}$ & $.118^{*}$ & .005 & $.328^{* * * *}$ & $-.322 * * *$ \\
\hline Austria & $.344^{*}$ & $.732^{* * *}$ & $.606^{* * *}$ & -.263 & .126 & $-.389 * *$ \\
\hline Belgium & $.672^{* * * *}$ & $.802 * * *$ & .097 & $.576^{* * *}$ & $.705^{* * *}$ & -.129 \\
\hline Brazil & $.366^{* * *}$ & $.968 * * *$ & $.102^{* *}$ & $.264^{* *}$ & $.867^{* * *}$ & $-.603^{* * 4}$ \\
\hline Canada & .093 & $.416^{* * *}$ & $.313 * * *$ & $-.220^{* * *}$ & $.103^{*}$ & $-.323 * * *$ \\
\hline Switzerland & $.472 * \cdots$ & $.845^{* * *}$ & $.672^{* * *}$ & -.201 & .172 & $-.373^{* * * *}$ \\
\hline Spain & $.276 * * *$ & $.538 * 0$ & $.532 * * *$ & $-.256^{* * * *}$ & .007 & $-.262^{* * *}$ \\
\hline Finland & $.329 * *$ & $.731^{* * *}$ & .026 & $.303^{* *}$ & $.706^{4 * *}$ & $-.403 * * *$ \\
\hline France & $.638 * * t$ & $.660 * 16 *$ & -.007 & $.645^{* * *}$ & $.667^{* * *}$ & -.022 \\
\hline U.K. & $.364^{* * *}$ & $.439 * * *$ & $.102^{* * *}$ & $.262^{* * *}$ & $.337^{* * *}$ & $-.075^{*}$ \\
\hline Hong Kong & -.037 & .187 & -.084 & .047 & $.272^{* *}$ & $-.224^{*}$ \\
\hline India & .125 & $.491^{* * *}$ & -.020 & .145 & $.511^{* 0 *}$ & $-.366^{* * *}$ \\
\hline Italy & $.310 * * *$ & $.492 * * *$ & -.002 & $.312^{*}$ & $.494 * * *$ & $-.182^{*}$ \\
\hline Japan & $.551^{* * * *}$ & $.824^{* * * *}$ & $.417^{* * *}$ & $.133^{* * *}$ & $.407^{* * *}$ & $-.273^{* * *}$ \\
\hline Korea & $.556 * * *$ & $.612^{4 * * 4}$ & $.509 * * *$ & .047 & .103 & -.055 \\
\hline Mexico & $.180^{*}$ & $.685^{* * 4}$ & $.135^{* *}$ & .045 & $.550^{* * *}$ & $-.505 * * *$ \\
\hline Malaysia & -.071 & .118 & $-.299^{* *}$ & .228 & $.417^{* * *}$ & -.189 \\
\hline Netheriands & .082 & $.721^{* * * *}$ & $.207 * *$ & -.125 & $.514^{* * *}$ & $-.639 * 4 *$ \\
\hline Norway & $.410^{* * * *}$ & $.914^{* * *}$ & -.498 & $.908^{* *}$ & $1.412^{* * *}$ & $-.504^{*}$ \\
\hline New Zealand & $.536^{* * *}$ & $.966^{* * *}$ & $1.720^{* * *}$ & $-1.184^{* *}$ & -.754 & $-.430^{* *}$ \\
\hline Pakistan & $.436^{* * * *}$ & $.546^{* * *}$ & .059 & $.377^{* * *}$ & $.487^{* * *}$ & -.110 \\
\hline Singapore & $-.223 * * *$ & $.165^{* *}$ & $-.583^{* * *}$ & $.360^{* * *}$ & $.748^{* * *}$ & $-.387 * * *$ \\
\hline Sweden & .111 & $.315^{* * *}$ & .108 & .003 & .207 & -.204 \\
\hline Thailand & $.149 * * *$ & $.357^{* * *}$ & .062 & .086 & $.295^{* * *}$ & $-.208^{* * *}$ \\
\hline Turkey & -.102 & $.625^{* * *}$ & $-.291 * * *$ & .189 & $.916^{* * *}$ & $-.727^{* * *}$ \\
\hline U.S. & $.105^{* * *}$ & $.419 * * *$ & $.222^{* * *}$ & $-.116^{* * *}$ & $.198^{* * *}$ & $-.3\left[4^{* * *}\right.$ \\
\hline S. Africa & .107 & $.255^{* * *}$ & .156 & -.048 & .100 & -.148 \\
\hline
\end{tabular}

\#**;* and * indicate statistical significance at 1,5 , and 10 percent levels, respectively. 


\section{Table III \\ Proportion of Firms Growing Faster than Predicted}

For each firm internal growth rate $\left(I_{G}\right)$ is given by $\left(R O A_{t} x b\right) /\left(1-R O A_{t} x b\right)$ where $R O A_{t}$ is the firm's return on assets and $b$ is the proportion of the firm's earnings that are retained for reinvestment at time $t$. Maximum short-term financed growth rate (MSFG) is defined as ROLTC $/\left(1-R_{2}\right.$ OLTC $)$ where ROLTC is the ratio of eamings, after tax and interest, to long term capital. Maximum sustainable growth rate $\left(M S G R_{t}\right)$ is given by $R E_{\mathfrak{t}}\left(1-R E_{t}\right)$ where $R O E_{t}$ is the return on equity. For each firm, these growth rates are calculated annually. For each country, the proportion of firms whose mean annual growth rate of sales exceeds the means of the three constrained growth rates (IGR, MSFG, MSGR) are presented below.

\begin{tabular}{|c|c|c|c|}
\hline & Proportion of firms that exceed & their: & \\
\hline & $\begin{array}{l}\text { Internal growth rate } \\
\mathrm{IGR}=(\mathrm{ROAxb}) /(1-\mathrm{ROAxb})\end{array}$ & $\begin{array}{l}\text { Maximum short-term financed } \\
\text { growth rate } \\
\text { MSFG=ROLTC/(1-ROLTC) }\end{array}$ & $\begin{array}{l}\text { Maximum sustainable growth rate } \\
\text { MSGR=ROE/(1-ROE) }\end{array}$ \\
\hline Australia & 0.58 & 0.41 & 0.34 \\
\hline Austria & 0.54 & 0.43 & 0.32 \\
\hline Belgium & 0.49 & 0.33 & 0.18 \\
\hline Brazil & 0.38 & 0.37 & 0.37 \\
\hline Canada & 0.57 & 0.47 & 0.36 \\
\hline Switzerland & 0.53 & 0.39 & 0.29 \\
\hline Germany & 0.60 & 0.48 & 0.30 \\
\hline Spain & 0.58 & 0.41 & 0.32 \\
\hline Finland & 0.55 & 0.44 & 0.23 \\
\hline France & 0.59 & 0.38 & 0.22 \\
\hline U.K. & 0.55 & 0.32 & 0.26 \\
\hline Hong Kong & 0.52 & 0.35 & 0.31 \\
\hline India & 0.58 & 0.38 & 0.25 \\
\hline Italy & 0.44 & 0.31 & 0.20 \\
\hline Jordan & 0.55 & 0.40 & 0.37 \\
\hline Japan & 0.68 & 0.52 & 0.38 \\
\hline Korea & 0.67 & 0.56 & 0.43 \\
\hline Mexico & 0.47 & 0.44 & 0.42 \\
\hline Malaysia & 0.63 & 0.48 & 0.42 \\
\hline Netherlands & 0.58 & 0.34 & 0.22 \\
\hline Norway & 0.54 & 0.48 & 0.23 \\
\hline New Zealand & 0.50 & 0.40 & 0.30 \\
\hline Pakistan & 0.50 & 0.28 & 0.19 \\
\hline Singapore & 0.61 & 0.50 & 0.45 \\
\hline Sweden & 0.45 & 0.30 & 0.15 \\
\hline Thailand & 0.71 & 0.50 & 0.41 \\
\hline Turkey & 0.50 & 0.23 & 0.18 \\
\hline U.S. & 0.55 & 0.42 & 0.31 \\
\hline S. Africa & 0.35 & 0.19 & 0.14 \\
\hline Zimbabwe & 0.54 & 0.37 & 0.30 \\
\hline
\end{tabular}




\section{Table IV}

\section{Firms Growing Above Predicted Rates and Their Characteristics}

The estimated model is: Excess Growth ${ }_{\text {Firm i] }}=\alpha+\beta_{1}$ NFATA $_{i}+\beta_{2}$ DIVTA $_{i}+\beta_{3}$ PROFIT $_{i}+\beta_{4}$ TAGDP $_{i}+\beta_{5}$ NSNFA $_{i}$

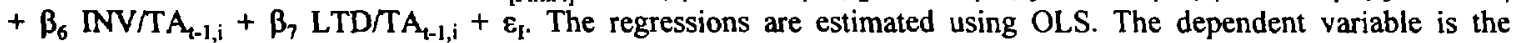
proportion of years in the sample period that a firm grows above its maximum short term financed growth rate, which is defined as ROLTC $/\left(1-R_{0} O L T C\right)$ where $R_{t} O L T C_{t}$ is the ratio of earnings, after tax and interest, to long term capital. Firm characteristics are averaged over the firms' sample period, so that each firm has one observation. NFATA is the net fixed assets divided by total assets. DIVTA is the dividends divided by total assets. PROFIT is the income before interest and taxes divided by total assets. TAGDP is the total assets of the firm divided by the GDP of the country. NSNFA is the net sales divided by net fixed assets. INV/TA $A_{t-1}$ is total investment divided by total assets in the previous period. LTD/TA $\mathrm{Tt}_{-1}$ is long term debt divided by total assets in the previous period. The regressions include an intercept whose coefficients are not reported.

\begin{tabular}{|c|c|c|c|c|c|c|c|}
\hline & NFATA & DIVTA & PROFIT & TAGDP & NSNFA & INV/TA $A_{t-1}$ & $\mathrm{LTD} / \mathrm{T} \mathrm{A}_{\mathrm{t}-1}$ \\
\hline Australia & .021 & -.935 & $-1.349^{* * *}$ & -2.248 & .000 & $.264^{*+*}$ & .160 \\
\hline Austria & .005 & 3.520 & $-2.059^{* *}$ & $6.180^{* *}$ & .001 & .436 & .109 \\
\hline Belgium & -.086 & -2.941 & -.659 & -2.014 & .001 & $.896^{* * *}$ & -.296 \\
\hline Brazil & -.021 & 4.874 & -.029 & 6.146 & .029 & -.064 & -.143 \\
\hline Canada & $-.136^{*}$ & $-6.500^{* * *}$ & $-.764 * * *$ & $-7.537^{* *}$ & $-.009^{* *}$ & .004 & .093 \\
\hline Switzerland & $-.330^{* *}$ & .540 & $-2.371^{* * *}$ & -.223 & $-.006^{*}$ & $.551^{* * *}$ & $.916^{* * *}$ \\
\hline Germany & -.087 & $-2.138^{*}$ & $-.688 * * *$ & -3.920 & -.001 & $.805^{* * *}$ & -.208 \\
\hline Spain & -.139 & -.682 & $-2.192^{* * *}$ & 4.133 & .004 & .004 & .549 \\
\hline Finland & -.074 & -3.812 & $-3.759 *$ & -4.307 & -.011 & .360 & -.581 \\
\hline France & .060 & -1.435 & $-1.087 * * *$ & -2.802 & .001 & $.216^{* * *}$ & $.309^{* *}$ \\
\hline U.K. & -.022 & $-2.200^{* * *}$ & $-1.062^{* * * *}$ & $-20.077^{* * *}$ & $.002^{*}$ & $.338^{* * *}$ & $.412^{* * *}$ \\
\hline Hong Kong & .140 & -.574 & $-1.085^{*}$ & -1.613 & .000 & $.392^{* *}$ & .365 \\
\hline India & -.046 & 1.138 & $-1.275^{* *}$ & -13.657 & .002 & $1.108 * * *$ & $.576^{*}$ \\
\hline Italy & .288 & -5.940 & -1.260 & .819 & .014 & $.520^{*}$ & -.191 \\
\hline Jordan & .320 & 1.257 & $-1.353^{*}$ & $-4.906^{* *}$ & .000 & $.700^{* *}$ & $1.225^{* *}$ \\
\hline Japan & $-.268 * * *$ & $-3.465^{*}$ & $-2.275^{* * *}$ & -1.772 & .000 & $1.821^{* * *}$ & $.395^{* * *}$ \\
\hline Korea & .114 & -5.624 & $-2.437^{* *}$ & 13.554 & .004 & $1.376^{* * *}$ & -.089 \\
\hline Mexico & .246 & n.a. & -.526 & $16.750^{* *}$ & -.067 & $.434^{*}$ & -.487 \\
\hline Malaysia & -.096 & $-5.254^{* * *}$ & .605 & 1.457 & -.004 & -.062 & -.123 \\
\hline Netherlands & -.041 & 2.412 & $-2.460^{* * *}$ & -2.505 & .000 & .109 & $.791 * * *$ \\
\hline Norway & .166 & 1.575 & $-2.013^{*}$ & -1.274 & .057 & .731 & .492 \\
\hline New Zealand & -.188 & -.484 & $-2.259^{*}$ & -.178 & .000 & .185 & .991 \\
\hline Pakistan & .210 & -.926 & -.372 & 11.131 & .000 & $.637^{* *}$ & $.795^{* * *}$ \\
\hline Singapore & -.083 & .458 & $-1.583^{* * *}$ & $1.327^{*}$ & -.004 & .145 & .157 \\
\hline Sweden & .234 & -.304 & -1.157 & .691 & -.006 & .258 & -.085 \\
\hline Thailand & .010 & -.266 & $-1.725^{* * *}$ & $-51.686^{* *}$ & .000 & $.576^{* * *}$ & .401 \\
\hline Turkey & $.563^{* * *}$ & $-2.431^{* * * *}$ & -.263 & -2.620 & .011 & .123 & -.071 \\
\hline U.S. & $-.173^{* * *}$ & $-3.001^{* * *}$ & $-1.177^{* * *}$ & $-53.009^{* * *}$ & $.001^{*}$ & $.879^{* * *}$ & $.289 * * *$ \\
\hline S. Africa & $-.434^{* *}$ & -1.993 & -.139 & 1.045 & .000 & $.102^{*}$ & -.530 \\
\hline Zimbabwe & n.a. & $-6.473 * *$ & $1.334^{* *}$ & $8.043^{*}$ & n.a. & $-.435^{*}$ & -.035 \\
\hline
\end{tabular}

$* *$ ** and * indicate statistical significance at 1,5 , and 10 percents, respectively. 


\section{Table V \\ Summary Statistics}

The proportion of firms that are growing faster than predicted is the proportion of firms in a country whose mean growth in sales exceed their mean maximum short term financed growth rates (MSFG). For each firm MSFG is defined as ROLTC/(1ROLTC) where ROLTC is the ratio of earnings, after tax and interest, to long term capital. MCAP/GDP is the stock market capitalization of the country divided by its GDP. TOR is stock market turnover defined as the total value of shares traded divided by market capitalization. NFLATION is the inflation rate of the GDP deflator. BANK/GDP is the total assets of the deposit money banks divided by GDP. LAW \& ORDER, scored 1 to 6 , is an indicator of the degree to which the citizens of a country are able to utilize the existing legal system to mediate disputes and enforce contracts. GROWTH is the growth rate of the real GDP per capita. GOV. SUBS./GDP are the grants on current account by the public authorities to (i) private industries and public corporations and (ii) government enterprises, divided by GDP. All country-level variables are annual figures, averaged over the 1980-1991 period. NFATA is the net fixed assets divided by total assets. DIVTA is the dividends divided by total assets. PROFIT is the income before interest and taxes divided by total assets. TAGDP is the total assets of the firms divided by the GDP of the country. NSNFA is the net sales divided by net fixed assets. INV/TA is total investment divided by total assets. LTD/TA is long term debt divided by total assets. All firm-level variables are averaged over firms in each country and over the 1980-1991 period. The following are the summary statistics for the 30 countries listed in Table I.

\begin{tabular}{lccccc}
\hline & $\mathrm{N}$ & Mean & Std Dev & Minimum & Maximum \\
\hline Proportion of firms that are growing faster than predicted (MSFG) & 30 & 0.396 & 0.086 & 0.192 & 0.564 \\
MCAP/GDP & 30 & 0.388 & 0.352 & 0.051 & 1.257 \\
TOR & 30 & 0.325 & 0.201 & 0.049 & 0.901 \\
INFLATION & 30 & 0.137 & 0.261 & 0.026 & 1.420 \\
BANK/GDP & 30 & 1.242 & 0.625 & 0.353 & 2.906 \\
LAW \& ORDER & 30 & 4.452 & 1.591 & 1.714 & 6.000 \\
GROWTH & 30 & 0.021 & 0.020 & -0.022 & 0.069 \\
GOV.SUBS./GDP & 26 & 3.164 & 2.298 & 0.600 & 10.933 \\
NFATA & 29 & 0.379 & 0.095 & 0.209 & 0.639 \\
DIVTA & 29 & 0.023 & 0.016 & 0.002 & 0.068 \\
TAGDP & 30 & 0.0003 & 0.0007 & 0.0000 & 0.0030 \\
PROFIT & 30 & 0.105 & 0.042 & 0.056 & 0.238 \\
NSNFA & 29 & 5.193 & 2.300 & 1.174 & 11.210 \\
INV/TA & 30 & 0.187 & 0.167 & 0.081 & 0.892 \\
LTD/TA & 30 & 0.214 & 0.103 & 0.079 & 0.481 \\
\hline
\end{tabular}




\section{Table VI}

\section{Proportion of Firms Growing Faster Than Predicted - Cross Country Results}

The regression equation estimated is: Excess Growth ${ }_{[\text {Country }=\mathrm{i}]}=\alpha+\beta_{1} \mathrm{MCAP}_{\mathrm{GDP}}+\beta_{2} \mathrm{TOR}_{\mathrm{i}}+\beta_{3}$ INFLATION $_{\mathrm{i}}+\beta_{4}$

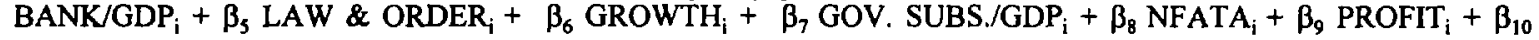
DIVTA $_{i}+\beta_{11}$ TAGDP $_{i}+\beta_{12}$ NSNFA NA $_{i}+\beta_{13}{\text { INV } / T A_{i}}+\beta_{14}$ LTD/TA $A_{i}+\beta_{15}$ (LTD/TA $x$ GOV. SUBS./GDP $)_{i}+\varepsilon_{i}$. Dependent variable is the proportion of firms that grow faster than their predicted growth rate. These are firms in a country whose mean growth in sales exceed their mean maximum short term financed growth rates (MSFG). For each firm MSFG is defined as ROLTC/(1-ROLTC) where ROLTC is the ratio of earnings, after tax and interest, to long term capital. MCAP/GDP is the stock market capitalization of the country divided by its GDP. TOR is stock market turnover defined as the total value of shares traded divided by market capitalization. INFLATION is the inflation rate of the GDP deflator. BANK/GDP is the total assets of the deposit money banks divided by GDP. LAW \& ORDER, scored 1 to 6 , is an indicator of the degree to which the citizens of a country are able to utilize the existing legal system to mediate disputes and enforce contracts. GROWTH is the growth rate of the real GDP per capita. GOV. SUBS./GDP are the grants on current account by the public authorities to (i) private industries and public corporations and (ii) government enterprises, divided by GDP. NFATA is the net fixed assets divided by total assets. DIVTA is the dividends divided by total assets. PROFIT is the income before interest and taxes divided by total assets. TAGDP is the total assets of the firms divided by the GDP of the country. NSNFA is the net sales divided by net fixed assets. INV/TA is total investment divided by total assets. LTD/TA is long term debt divided by total assets. All variables are averaged over the 1980-1991 period. White's heteroskedasticity-consistent standard errors are given in parantheses.

\begin{tabular}{|c|c|c|c|c|c|c|}
\hline & (1) & (2) & (3) & (4) & (5) & (6) \\
\hline INTERCEPT & $.127^{* *}$ & .224 & .114 & .177 & $.223^{* *}$ & .144 \\
\hline & $(.062)$ & $(.202)$ & $(.126)$ & $(.125)$ & $(.085)$ & $(.085)$ \\
\hline MCAP/GDP & .030 & .011 & -.034 & -.016 & -.011 & .004 \\
\hline & $(.044)$ & $(.038)$ & $(.033)$ & $(.032)$ & $(.034)$ & $(.033)$ \\
\hline TOR & $.241^{* * *}$ & $.191^{* *}$ & $.179 * * *$ & $.161 * * *$ & $.153^{* * *}$ & $.153 * * *$ \\
\hline & $(.045)$ & $(.091)$ & $(.032)$ & $(.030)$ & $(.027)$ & $(.031)$ \\
\hline INFLATION & .013 & $.136^{*}$ & -.048 & $\begin{array}{r}.009 \\
(063)\end{array}$ & .023 & -.034 \\
\hline BANK/GDP & $\begin{array}{l}-.014 \\
(.017)\end{array}$ & $\begin{array}{c}.008 \\
(.050)\end{array}$ & $\begin{array}{l}.012 \\
(.014)\end{array}$ & $\begin{array}{c}.010 \\
(.015)\end{array}$ & $\begin{array}{c}.011 \\
(.016)\end{array}$ & $\begin{array}{l}.014 \\
(.016)\end{array}$ \\
\hline LAW \& ORDER & $\begin{array}{l}.028 * * * \\
(.010)\end{array}$ & $\begin{array}{l}-.007 \\
(.014)\end{array}$ & $\begin{array}{l}.020^{* *} \\
(.009)\end{array}$ & $\begin{array}{l}.007 \\
(.011)\end{array}$ & & \\
\hline GROWTH & $\begin{array}{l}2.849 * * * \\
(.602)\end{array}$ & $\begin{array}{l}3.569^{* * *} \\
(.578)\end{array}$ & $\begin{array}{l}3.205^{* * *} \\
(.408)\end{array}$ & $\begin{array}{l}3.266^{* * *} \\
(.396)\end{array}$ & $\begin{array}{l}3.159^{* * *} \\
(.425)\end{array}$ & $\begin{array}{c}2.936^{* * * *} \\
(.423)\end{array}$ \\
\hline GOV. SUBS. & .000 & $-.014^{*}$ & -.008 & $-.013^{*}$ & $-.014^{* *}$ & \\
\hline /GDP & $(.007)$ & $(.008)$ & $(.006)$ & $(.007)$ & $(.006)$ & \\
\hline NFATA & & $\begin{array}{r}.184 \\
(.164)\end{array}$ & $\begin{array}{l}.467^{* * *} \\
(.130)\end{array}$ & $\begin{array}{l}.403^{* * *} \\
(.138)\end{array}$ & $\begin{array}{l}.377^{* * *} \\
(.126)\end{array}$ & $\begin{array}{c}.412^{* * *} \\
(.130)\end{array}$ \\
\hline PROFIT & & $\begin{array}{l}-1.226^{*} \\
(.655)\end{array}$ & $\begin{array}{l}-.858^{* * *} \\
(.297)\end{array}$ & $\begin{array}{l}-1.012^{* * *} \\
(.294)\end{array}$ & $\begin{array}{c}-1.112^{* * *} \\
(.187)\end{array}$ & $\begin{array}{c}-.907^{* * *} \\
(.176)\end{array}$ \\
\hline DIVTA & & $\begin{array}{c}3.551 \\
(2.888)\end{array}$ & & & & \\
\hline TAGDP & & $\begin{array}{c}-2.709 \\
(19.291)\end{array}$ & & & & \\
\hline NSNFA & & $\begin{array}{l}-.004 \\
(.009)\end{array}$ & & & & \\
\hline INV/TA & & $\begin{array}{l}-.215 \\
(.394)\end{array}$ & & & & \\
\hline LTD/TA & & $\begin{array}{l}.517^{*} \\
(.229)\end{array}$ & & $\begin{array}{l}.209^{*} \\
(.110)\end{array}$ & $\begin{array}{l}.257^{* * * *} \\
(.094)\end{array}$ & $\begin{array}{c}.410^{* * *} \\
(.132)\end{array}$ \\
\hline $\begin{array}{l}\text { LTD/TA X GOV. } \\
\text { SUBS. /GDP }\end{array}$ & & & & & & $\begin{array}{c}-.043^{* *} \\
(.023)\end{array}$ \\
\hline $\operatorname{adj} . R^{2}$ & .46 & .61 & .69 & .70 & .72 & .68 \\
\hline No of Obs. & 26 & 25 & 26 & 26 & 26 & 26 \\
\hline
\end{tabular}

***,** and * indicate statistical significance at 1,5 and 10 percents, respectively. 


\section{Table VII \\ Sensitivity Tests Allowing Different Marginal Profit Rates}

The regression equation estimated is: Excess Growth CCountry-i] $=\alpha+\beta_{1}$ MCAP/GDP ${ }_{i}+\beta_{2}$ TOR $_{i}+\beta_{3}$ INFLATION $_{i}+\beta_{4}$ BANKJGDP $_{i}+\beta_{5}$ LAW \& ORDER $i+\beta_{6}$ GROWTH $_{i}+\beta_{7}$ GOV. SUBS./GDP $i+\beta_{8}$ NFATA $_{i}+\beta_{9}$ PROFIT $_{i}+\varepsilon_{i}$. Dependent variable is the proportion of firms that grow faster than their predicted growth rate. These are firms in a country whose mean growth in sales exceed their mean maximum short term financed growth rates (MSFG). For each firm MSFG is defined as ROLTC/(1-zxROLTC) where ROLTC is the ratio of earnings, after tax and interest, to long term capital and $z$ is a parameter that measures the ratio of the profit rate on the new sales to the firm's average profits rate. Estimation results assuming different values of $\mathrm{z}$ are given below. MCAP/GDP is the stock market capitalization of the country divided by its GDP. TOR is stock market tumover defined as the total value of shares traded divided by market capitalization. INFLATION is the inflation rate of the GDP deflator. BANK/GDP is the total assets of the deposit money banks divided by GDP. LAW \& ORDER, scored 1 to 6 , is an indicator of the degree to which the citizens of a country are able to utilize the existing legal system to mediate disputes and enforce contracts. GROWTH is the growth rate of the real GDP per capita. GOV. SUBS./GDP are the grants on current account by the public authorities to (i) private industries and public corporations and (ii) government enterprises, divided by GDP. NFATA is the net fixed assets divided by total assets. PROFIT is the income before interest and taxes divided by total assets. All variables are averaged over the 1980-1991 period. White's heteroskedasticity-consistent standard errors are given in parantheses.

\begin{tabular}{|c|c|c|c|c|}
\hline & $z=1$ & $z=.75$ & $z=.5$ & $\mathrm{z}=0$ \\
\hline \multirow[t]{2}{*}{ INTERCEPT } & .114 & .120 & .138 & .146 \\
\hline & $(.126)$ & $(.126)$ & $(.129)$ & $(.132)$ \\
\hline \multirow[t]{2}{*}{ MCAP/GDP } & -.034 & -.033 & -.038 & -.040 \\
\hline & $(.033)$ & $(.033)$ & $(.034)$ & $(.034)$ \\
\hline \multirow[t]{2}{*}{ TOR } & $.179 * * *$ & $.180^{* * *}$ & $.172^{* * *}$ & $.165^{* * *}$ \\
\hline & $(.032)$ & $(.031)$ & $(.032)$ & $(.029)$ \\
\hline \multirow[t]{2}{*}{ INFLATION } & -.048 & -.046 & -.041 & -.037 \\
\hline & $(.045)$ & $(.045)$ & $(.045)$ & $(.045)$ \\
\hline \multirow[t]{2}{*}{ BANK/GDP } & .012 & .011 & .011 & .009 \\
\hline & $(.014)$ & $(.013)$ & $(.014)$ & $(.013)$ \\
\hline \multirow[t]{2}{*}{ LAW \& ORDER } & $.020 * *$ & $.019 * *$ & $.019 * *$ & $.019^{* *}$ \\
\hline & $(.009)$ & $(.009)$ & $(.009)$ & $(.009)$ \\
\hline \multirow[t]{2}{*}{ GROWTH } & $3.205^{* * *}$ & $3.255^{* * *}$ & $3.365^{* * *}$ & $3.591^{* * *}$ \\
\hline & $(.408)$ & $(.383)$ & $(.371)$ & $(.380)$ \\
\hline \multirow[t]{2}{*}{ GOV. SUBS./GDP } & -.008 & $-.008^{*}$ & $-.008^{*}$ & -.009 \\
\hline & $(.006)$ & $(.005)$ & $(.005)$ & $(.006)$ \\
\hline \multirow[t]{2}{*}{ NFATA } & $.467 * * *$ & $.458^{* 4 *}$ & $.433 * *$ & $.429 * * *$ \\
\hline & $(.130)$ & $(.129)$ & $(.135)$ & $(.139)$ \\
\hline \multirow[t]{2}{*}{ PROFIT } & $-.858 * * *$ & $-.819 * * *$ & $-.791 * *$ & $-.681 * *$ \\
\hline & $(.297)$ & $(.292)$ & $(.296)$ & $(.299)$ \\
\hline adj. $R^{2}$ & .69 & .69 & .68 & .68 \\
\hline No of Obs. & 26 & 26 & 26 & 26 \\
\hline
\end{tabular}

$* * *, * *$ and * indicate statistical significance at 1,5 and 10 percents, respectively. 


\section{Table VIII \\ Sensitivity Tests -Replacing Sales Growth with Asset Growth and Adjusting for Inflation}

The regression equation estimated is: Excess Growth Country-i] $=\alpha+\beta_{1}$ MCAP/GDP $_{i}+\beta_{2}$ TOR $_{i}+\beta_{3}$ INFLATION $_{i}+$ $\beta_{4}$ BANK/GDP $+\beta_{5}$ LAW \& ORDER OR $_{i}+\beta_{6}$ GROWTH $_{i}+\beta_{7}$ GOV. SUBS./GDP $_{i}+\beta_{8}$ NFATA $_{i}+\beta_{9}$ PROFIT $_{i}+\varepsilon_{i}$. Dependent variable of specification reported in column (1) is the proportion of firms that grow faster than their predicted growth rate. These are firms in a country whose mean growth in sales exceed their mean maximum short term financed growth rates (MSFG). For each firm MSFG is defined as ROLTC/(1-ROLTC) where ROLTC is the ratio of earnings, after tax and interest, to long term capital. In the specification reported in column (2) mean growth in sales is replaced by mean growth in assets. In column (3) the specification in column (1) is reestimated using an adjustment for the effect of inflation on firms' assets and earnings. The value of the firms' total assets (TA) required to support sales at time $t+1$ in time $t$ dollars is given by $(\operatorname{TA}(t+1) / 1+\pi)+(\pi / 1+\pi) \times(T A(t)-D E P(t+1))$ where $\pi$ is the rate of inflation between time $t$ and $t+1$ and DEP(t) is the depreciation of the firm's long-term assets between $t$ and $t+1$. MCAP/GDP is the stock market capitalization of the country divided by its GDP. TOR is stock market turnover defined as the total value of shares traded divided by market capitalization. INFLATION is the inflation rate of the GDP deflator. BANK/GDP is the total assets of the deposit money banks divided by GDP. LAW \& ORDER, scored 1 to 6 , is an indicator of the degree to which the citizens of a country are able to utilize the existing legal system to mediate disputes and enforce contracts. GROWTH is the growth rate of the real GDP per capita. GOV. SUBS./GDP are the grants on current account by the public authorities to (i) private industries and public corporations and (ii) government enterprises, divided by GDP. NFATA is the net fixed assets divided by total assets. PROFIT is the income before interest and taxes divided by total assets. All variables are averaged over the 1980-1991 period. White's heteroskedasticity-consistent standard errors are given in parantheses.

\begin{tabular}{|c|c|c|c|}
\hline & (1) & (2) & (3) \\
\hline \multirow[t]{2}{*}{ INTERCEPT } & .114 & .257 & -.348 \\
\hline & $(.126)$ & $(.231)$ & $(.242)$ \\
\hline \multirow[t]{2}{*}{$\mathrm{MCAP} / \mathrm{GDP}$} & -.034 & -.074 & -.027 \\
\hline & $(.033)$ & $(.073)$ & $(.077)$ \\
\hline \multirow[t]{2}{*}{ TOR } & $.179 * * *$ & $.160^{* *}$ & $.129 * *$ \\
\hline & $(.032)$ & $(.061)$ & $(.055)$ \\
\hline \multirow[t]{2}{*}{ INFLATION } & -.048 & .007 & .091 \\
\hline & $(.045)$ & $(.005)$ & $(.080)$ \\
\hline \multirow[t]{2}{*}{ BANK/GDP } & .012 & -.025 & $.045^{* *}$ \\
\hline & $(.014)$ & $(.026)$ & $(.017)$ \\
\hline \multirow[t]{2}{*}{ LAW \& ORDER } & $.020^{* *}$ & $.037 * * *$ & $.043 * * *$ \\
\hline & $(.009)$ & $(.013)$ & $(.014)$ \\
\hline \multirow[t]{2}{*}{ GROWTH } & $3.205^{* * *}$ & $4.116^{* * *}$ & $3.495^{* *}$ \\
\hline & $(.408)$ & $(.792)$ & $(1.659)$ \\
\hline \multirow[t]{2}{*}{ GOV. SUBS./GDP } & -.008 & $-.019 * * *$ & -.007 \\
\hline & $(.006)$ & $(.005)$ & $(.011)$ \\
\hline \multirow[t]{2}{*}{ NFATA } & $.467 * * *$ & .139 & $.477^{* * *}$ \\
\hline & $(.130)$ & $(.176)$ & $(.171)$ \\
\hline \multirow[t]{2}{*}{ PROFIT } & $-.858 * * *$ & $-1.034^{* * *}$ & $2.645 * * *$ \\
\hline & $(.297)$ & $(.376)$ & $(.759)$ \\
\hline adj. $R^{2}$ & .69 & .44 & .43 \\
\hline No of Obs. & 26 & 26 & 26 \\
\hline
\end{tabular}

$* * *, *$ and * indicate statistical significance at 1,5 and 10 percents, respectively. 


\section{Appendix}

Number of Firms and the Sample Period

\begin{tabular}{|c|c|c|}
\hline & No.of Firms & Time Period \\
\hline Australia & 401 & $1983-91$ \\
\hline Austria & 44 & $1983-91$ \\
\hline Belgium & 89 & $1983-91$ \\
\hline Brazil* & 100 & $1985-91$ \\
\hline Canada & 494 & $1983-91$ \\
\hline Switzerland & 150 & $1983-91$ \\
\hline Germany & 359 & $1983-91$ \\
\hline Spain & 116 & $1983-91$ \\
\hline Finland & 55 & $1983-91$ \\
\hline France & 544 & $1983-91$ \\
\hline United Kingdom & 1275 & $1983-91$ \\
\hline Hong Kong & 173 & $1983-91$ \\
\hline India* & 100 & $1980-90$ \\
\hline Italy & 81 & $1983-91$ \\
\hline Jordan* & 38 & $1980-90$ \\
\hline Japan & 1104 & $1983-91$ \\
\hline Korea* & 100 & $1980-90$ \\
\hline Mexico* & 100 & $1984-91$ \\
\hline Malaysia & 143 & $1983-91$ \\
\hline Netherlands & 165 & $1983-91$ \\
\hline Norway & 52 & $1983-91$ \\
\hline New Zealand & 41 & $1983-91$ \\
\hline Pakistan* & 100 & $1980-88$ \\
\hline Singapore & 213 & $1983-91$ \\
\hline Sweden & 68 & $1983-91$ \\
\hline Thailand & 137 & $1983-91$ \\
\hline Turkey* & 45 & $1982-90$ \\
\hline United States & 3247 & $1983-91$ \\
\hline South Africa & 67 & $1983-91$ \\
\hline Zimbabwe* & 48 & $1980-88$ \\
\hline
\end{tabular}

For those countries with *, the data source for the firm level variables is IFC's corporate finance data base. Otherwise, the data are from Global Vantage data base. 


\section{Variable Definitions and Sources}

\section{Firm-level data:}

Global Vantage definitions:

Variables are from the industry/commercial tape of the Global Vantage data base, frozen as of December 1995.

investment $=$ total assets - total assets $_{\mathrm{t}-1}+$ depreciation

$=$ DA89-DA89 $9_{\mathrm{t}-1}+\mathrm{DA} 11$

PERRE $=($ earnings after taxes-dividends + depreciation $) /$ investment

( (DA21-DA23)-DA34+DA11)/investment

PERLTD $=\left((\text { DA 1 18-Da 104)-(DA } 118-D A 104)_{t-1}\right) /$ investment

PERSTD $=\left(\left(\right.\right.$ DA 104-DA 104 $\left.4_{t-1}\right) /$ investment

PEREQ $=($ investment-(DA21-DA23-DA34+DA11)-((DA118-DA 104)-(DA 1 18-DA 104)(-1)-(DA104DA $\left.\left.104_{\mathrm{t}-1}\right)\right)$ /investment

PERINV $=\left(\right.$ nfa-nfa $a_{t-1}+$ depreciation $) /$ investment $=\left(D A 76-D A 76_{t-1}+\right.$ DA 11$) /$ investment

PERCA $=\left(\mathrm{ca}_{-} \mathrm{ca}_{\mathrm{t}-1}\right) /$ investment $=\left(\mathrm{DA} 75-\mathrm{DA} 75_{\mathrm{t}-1}\right) /$ investment

PERRES $=\left((\right.$ ta-nfa-ca $\left.)-(\text { ta-nfa-ca })_{\text {t-1 }}\right) /$ investment= $=(($ DA89-DA76-DA75)-(DA89-DA76-DA75)tI/investment

Itd/ta $=($ total liabilitities-current liabilities $) /$ total assets=(DA118-DA104)/DA89

nfata $=$ net fixed assets/total assets $=$ DA76/DA89

profit $=($ EBIT + interest expense $) /$ total assets $=($ DA21 + DA15 $) / D A 89$

divta $=$ total dividends/total assets $=$ DA34/DA89

nsnfa $=$ total sales/net fixed assets $=$ DA $1 / D A 76$

For the countries for which data is taken from the IFC's corporate finance data base, variables were created according to the definitions give above.

Other data sources:

Inflation is the annual inflation of the GDP deflator and is obtained from World Bank National Accounts.

Real GDP per capita and its growth rate are obtained from World Bank National Reports.

bank/gdp is the ratio of deposit money banks domestic assets to GDP, obtained from the IMF, International Financial Statistics, various years. Deposit money domestic assets are the summation of IFS lines 22a through $22 \mathrm{f}$.

The Law and Order indicator is obtained from ICRG, International Country Risk Guide.

Government subsidies to private and public enterprises data are obtained from various issues of the World Competitiveness Report, The World Economic Forum \& IMD International, Geneva, Switzerland. 

Policy Research Working Paper Series

\begin{tabular}{|c|c|c|c|c|}
\hline & Title & Author & Date & $\begin{array}{l}\text { Contact } \\
\text { for paper }\end{array}$ \\
\hline WPS1665 & $\begin{array}{l}\text { How Important Are Labor Markets } \\
\text { to the Welfare of Indonesia's Poor? }\end{array}$ & $\begin{array}{l}\text { Andrew D. Mason } \\
\text { Jacqueline Baptist }\end{array}$ & October 1996 & $\begin{array}{l}\text { D. Ballantyne } \\
87198\end{array}$ \\
\hline WPS1666 & $\begin{array}{l}\text { Is Growth in Bangladesh's Rice } \\
\text { Production Sustainable? }\end{array}$ & $\begin{array}{l}\text { John Baffes } \\
\text { Madhur Gautam }\end{array}$ & October 1996 & $\begin{array}{l}\text { P. Kokila } \\
33716\end{array}$ \\
\hline WPS1667 & $\begin{array}{l}\text { Dealing with Commodity Price } \\
\text { Uncertainty }\end{array}$ & $\begin{array}{l}\text { Panos Varangis } \\
\text { Dan Larson }\end{array}$ & October 1996 & $\begin{array}{l}\text { J. Jacobson } \\
33710\end{array}$ \\
\hline WPS1668 & $\begin{array}{l}\text { Small is Beautiful: Preferential Trade } \\
\text { Agreements and the Impact of } \\
\text { Country Size, Market Share, } \\
\text { Efficiency, and Trade Policy }\end{array}$ & Maurice Schiff & October 1996 & $\begin{array}{l}\text { M. Patena } \\
39515\end{array}$ \\
\hline WPS1669 & $\begin{array}{l}\text { International Capital Flows: Do } \\
\text { Short-Term Investment and Direct } \\
\text { Investment Differ? }\end{array}$ & $\begin{array}{l}\text { Punam Chuhan } \\
\text { Gabriel Perez-Quiros } \\
\text { Helen Popper }\end{array}$ & October 1996 & $\begin{array}{l}\text { T. Nadora } \\
33925\end{array}$ \\
\hline WPS1670 & $\begin{array}{l}\text { Assessing the Welfare Impacts } \\
\text { of Public Spending }\end{array}$ & Dominique van de Walle & October 1996 & $\begin{array}{l}\text { C. Bernardo } \\
31148\end{array}$ \\
\hline WPS1671 & $\begin{array}{l}\text { Financial Constraints, Uses of Funds, } \\
\text { and Firm Growth: An International } \\
\text { Comparison }\end{array}$ & $\begin{array}{l}\text { Asli Demirgüç-Kunt } \\
\text { Vojislav Maksimovic }\end{array}$ & October 1996 & $\begin{array}{l}\text { P. Sintim-Aboagye } \\
37644\end{array}$ \\
\hline WPS1672 & $\begin{array}{l}\text { Controlling Industrial Pollution: } \\
\text { A New Paradigm }\end{array}$ & $\begin{array}{l}\text { Shakeb Afsah } \\
\text { Bemoit Laplante } \\
\text { David Wheeler }\end{array}$ & October 1996 & \\
\hline WPS1673 & $\begin{array}{l}\text { Indonesian Labor Legislation in a } \\
\text { Comparative Perspective: A Study } \\
\text { of Six APEC Countries }\end{array}$ & Reema Nayar & October 1996 & $\begin{array}{l}\text { R. Nayar } \\
33468\end{array}$ \\
\hline
\end{tabular}




\section{Policy Research Working Paper Series}

Title

WPS1651 Bank-Led Restructuring in Poland: Bankruptcy and Its Alternatives

WPS1652 Intra-Industry Trade, Foreign Direct Investment, and the Reorientation of Eastern European Exports

WPS1653 Grants and Debt Forgiveness in Africa: A Descriptive Analysis

WPS1654 Indonesia's Palm Oil Subsector

WPS1655 Uncertainty and the Price for Crude Oil Reserves

WPS1656 The Investment Decision: A Re-Examination of Competing Theories Using Panel Data

WPS1657 Is There an Optimal Structure for Decentralized Provision of Roads?

WPS1658 Decentralizing Structures for Providing Roads: A Cross-Country Comparison

WPS1659 Unemployment Insurance in Algeria: Implications for a Labor Market in Transition

WPS1660 Mind Your P's and Q's: The Cost of Public Investment is Not the

Value of Public Capital

WPS1661 Determinants of Public Expenditure on Infrastructure: Transportation and Communication

WPS1662 From Learning to Partnership: Multinational Research and Development Cooperation in Developing Countries

WPS1663 Internal Finance and Investment: Another Look

WPS1664 Pensions in Germany
Author

Cheryl W. Gray

Arnold Holle

Bernard Hoekman

Simeon Djankov

Leonardo Hernández

Donald F. Larson

Timothy J. Considine

Donald F. Larson

Cherian Samuel

Frannie Humplick

Azadeh Moini-Araghi

Frannie Humplick

Azadeh Moini-Araghi

Elizabeth Ruppert

Lant Pritchett

Susan Randolph

Zeljko Bogetic

Dennis Heffley

Giorgio Barba Navaretti Carlo Carraro

Cherian Samuel

Monika Queisser
October 1996

October 1996

Date

September 1996

September 1996

September 1996

R. Vo

31047

September 1996

September 1996

September 1996

September 1996

September 1996

September 1996

H. Osselyn 36039

October 1996

S. Fallon 38009

October 1996

Z. Bogetic 623-7292

M. Patena 39515

C. Samuel 30802

October 1996

H. Arbi 34663 